\title{
Respiratory Viral Infections in Hematopoietic Stem Cell and Solid Organ Transplant Recipients
}

\author{
S. Samuel Weigt, M.D. ${ }^{1}$, Aric L. Gregson, M.D. ${ }^{2}$, Jane C. Deng, M.D. ${ }^{1}$, Joseph P. Lynch III, \\ M.D. ${ }^{1}$, and John A. Belperio, M.D. ${ }^{1}$ \\ ${ }^{1}$ Division of Pulmonary, Critical Care Medicine, Allergy, and Clinical Immunology, Department of \\ Medicine, The David Geffen School of Medicine at UCLA, Los Angeles, California \\ 2Division of Infectious Diseases, Department of Medicine, The David Geffen School of Medicine \\ at UCLA, Los Angeles, California
}

\section{Abstract}

Respiratory viral infections (RVIs) are common causes of mild illness in immunocompetent children and adults with rare occurrences of significant morbidity or mortality. Complications are more common in the very young, very old, and those with underlying lung diseases. However, RVIs are increasingly recognized as a cause of morbidity and mortality in recipients of hematopoietic stem cell transplants (HSCT) and solid organ transplants (SOTs). Diagnostic techniques for respiratory syncytial virus (RSV), parainfluenza, influenza, and adenovirus have been clinically available for decades, and these infections are known to cause serious disease in transplant recipients. Modern molecular technology has now made it possible to detect other RVIs including human metapneumovirus, coronavirus, and bocavirus, and the role of these viruses in causing serious disease in transplant recipients is still being worked out. This article reviews the current information regarding epidemiology, pathogenesis, clinical presentation, diagnosis, and treatment of these infections, as well as the aspects of clinical significance of RVIs unique to HSCT or SOT.

\section{Keywords}

Respiratory viral infection (RVI); transplant; community acquired respiratory virus (CARV); respiratory syncytial virus; influenza; parainfluenza

\begin{abstract}
Respiratory viral infections (RVIs) are a significant cause of morbidity and mortality in the immunocompromised host. Traditionally, the laboratory diagnosis of respiratory viruses has been difficult and limited to relatively few viruses. Virus isolation in cell lines generally provides results in 8 to 10 days. Direct fluorescent antibody (DFA) testing using a nasopharyngeal aspirate or swab has also been available in most clinical laboratories and
\end{abstract}

\footnotetext{
Copyright (C) 2011 by Thieme Medical Publishers, Inc.

Address for correspondence and reprint requests: S. Samuel Weigt, M.D., Division of Pulmonary, Critical Care Medicine, and Hospitalists, The David Geffen School of Medicine at UCLA, 10833 Le Conte Ave., Rm. CHS 37-131, Los Angeles, CA 90095 (sweigt@mednet.ucla.edu).

Respiratory Viral Infections; Guest Editors, Adriana Weinberg, M.D. and Martin R. Zamora, M.D.
} 
provides a rapid result in 3 to 5 hours. However, this test is commonly limited to influenza, parainfluenza, respiratory syncytial virus (RSV), and adenovirus (AdV). Sensitivity of detection may also be limited. In the past decade, nucleic acid amplification testing (NAT) played a leading role in the diagnosis of RVI. Multiplex polymerase chain reaction (PCR), microbead detection, and DNA microarrays have the capability of searching for several viruses in one test. In general, NAT testing is more sensitive than other methods, and the detection of some viruses (eg, human bocavirus) is dependent on NAT. Most studies of RVI in transplant recipients are retrospective, focus on symptomatic patients, and utilize culture or DFA tests for diagnosis. These methods likely lead to underestimates of incidence and overestimate severity, and can be difficult to apply to clinical practice today. This review describes the current knowledge of RVI as it relates to hematopoietic stem cell transplant (HSCT) and solid organ transplant (SOT) recipients and provides the reader with the knowledge required to make informed decisions about the care of these patients.

\section{RESPIRATORY SYNCYTIAL VIRUS}

\section{Epidemiology and Transmission}

RSV is a common cause of seasonal RVI in immunocompetent hosts of all ages. In the United States, most RSV infections occur in the months of November to April. ${ }^{1}$ Among healthy, nonelderly adults, RSV usually causes only mild, self-limited, upper respiratory tract illness. However, RSV is the most common cause of lower respiratory tract infection (LRTI) in children younger than 1 year. ${ }^{1}$ Almost all children are infected with RSV by 2 years of age, and reinfection is common. RSV is also a frequent, and often unrecognized, cause of LRTI in the elderly, with up to $7 \%$ of the healthy elderly infected annually. ${ }^{2}$ In elderly patients hospitalized with RSV infection, length of stay and need for intensive care are similar to those seen with influenza $\mathrm{A}$, and mortality rates ( 8 and $7 \%$, respectively) are also similar. ${ }^{2}$ Additional risk factors for lower respiratory tract disease include age less than 6 months, ${ }^{3}$ preterm birth infants, those with lung disease ${ }^{3,4}$ or cardiopulmonary disease, ${ }^{3,5}$ and immunocompromised individuals. ${ }^{6-9}$ RSV infections are also common in healthy, nonelderly adults but usually cause only mild, self-limited, upper respiratory tract infections (URIs).

Among HSCT recipients, RSV is a common cause of seasonal respiratory tract infections. HSCT recipients infected with RSV are especially vulnerable to infection of the lower respiratory tract. Factors reported to elevate the risk of LRTI include allogeneic transplant, mismatched/unrelated transplant, graft versus host disease, myeloablative regimens, advanced age, infection within 1 month of transplantation, and prolonged lymphopenia. ${ }^{10-15}$ RSV LRTI is a strong predictor of mortality in HSCT patients, with an associated mortality reported to range from $7 \%$ to $83 \% .{ }^{16} \mathrm{~A}$ general trend for improved rates of survival over time may in part be explained by increased awareness and improvements in care of these patients. ${ }^{16}$

The incidence and severity of RSV infections in lung transplant recipients have been described in multiple retrospective series. ${ }^{17-22}$ In one prospective study of 50 lung transplant recipients, eight (16\%) patients contracted RSV infection during a single season. ${ }^{21}$ However, in a similar single-season study of 388 lung transplant recipients, only 
seven (2\%) were diagnosed with RSV infection. ${ }^{23}$ Importantly, severe LRTIs have been described in lung transplant recipients, and mortality rates attributable to RSV range from 10 to $20 \% .{ }^{17-22}$

Studies reporting the incidence and spectrum of RSV infections in SOT recipients, other than lung recipients, are sparse. A study of pediatric renal transplant recipients found that the spectrum of RSV infections was similar to that reported in normal children. ${ }^{24}$ Another study of pediatric liver transplant recipients also reported that the clinical spectrum of RSV infections was similar to that seen in normal children, but concluded that early onset of infection (within 20 days of transplant) and preexisting lung disease were risk factors for more severe disease. ${ }^{25}$ Augmented immunosuppression and age less than 1 year have also been associated with increased severity of disease among SOT recipients. ${ }^{26}$

Transmission of RSV most commonly occurs by direct inoculation of the mouth, nose, or eyes after contact with virus-containing secretions or fomites. ${ }^{27,28}$ However, spread via large aerosolized droplets has also been implicated. ${ }^{29}$ RSV can survive for several hours on hands and contaminated surfaces. ${ }^{30}$ Nosocomial transmission of RSV has been reported on HSCT units ${ }^{13,31-34}$ and in the HSCT clinic. ${ }^{35}$ The duration of viral shedding may be prolonged in HSCT patients and ranged from 7 to 84 days in one study. ${ }^{36}$

\section{Pathogenesis}

After replicating in the nasopharynx, RSV extends to the lower respiratory tract, presumably by aspiration of secretions. ${ }^{37}$ Pathological findings include proliferation of the bronchial epithelium, epithelial necrosis, and infiltration of monocytes and T-cells centered on airways and pulmonary arterioles. ${ }^{38}$ A finding of neutrophilia in bronchoalveolar lavage (BAL) fluid has also been de-scribed. ${ }^{39} \mathrm{RSV}$ infection is restricted to the respiratory epithelium and only rarely has been isolated from extrapulmonary tissues. ${ }^{40,41}$

The immune response to RSV includes a vigorous production of cytokines and chemokines, including interleukin-1 beta (IL-1 $\beta$ ), tumor necrosis factor alpha (TNF- $\alpha$ ), IL-8, IL-6, CCL3, and CCL5. ${ }^{42-49}$ Concentrations of these immune response cytokines/chemokines in respiratory secretions may correlate with the severity of the disease. ${ }^{43,49}$ However, it is not yet evident whether these immune response cytokines/chemokines directly cause damage, or if they merely represent a stronger immune response stimulated by a higher burden of RSV .

\section{Clinical Presentation and Complications}

RSV is one of the most common causes of RVI in transplant recipients. Initial manifestations of RSV infection are usually limited to upper respiratory tract symptoms including congestion and rhinorrhea. However, among immunocompromised patients, RSV upper URI may quickly progress to LRTI, including life-threatening pneumonia. According to one recent literature review of HSCT patients, the progression rate to LRTI was $68 \%$ (76/112) in untreated patients. ${ }^{50}$ Moreover, the risk of mortality is high among those patients who progress to LRTI. RSV attributable mortality was $32 \%$ among the 437 HSCT patients diagnosed with LRTI. ${ }^{50}$ 
Among patients with RSV LRTI, the incidence of coinfection with another virulent pathogen may be lower with RSV relative to other respiratory viruses. In one study of HSCT patients, the incidence of coinfection was 25\% (3/12) in patients infected with RSV as compared with $100 \%$ (7/7) of those infected with influenza and 41\% (11/27) infected with parainfluenza. ${ }^{51}$ In another study, $14 \%$ (1/7) of HSCT patients with LRTI due to RSV developed invasive aspergillosis, as opposed to $57 \%$ (4/7) and 75\% (3/4) of those with influenza and parainfluenza infection, respectively. ${ }^{52}$

RSV infection may have a unique association with subsequent pulmonary sequelae. Among infants, severe RSV infection is associated with an increased risk of reactive airways disease. ${ }^{53-57}$ Moreover, even among previously healthy adults, RSV infection is associated with altered airway activity 8 weeks after infection. ${ }^{58}$ Pulmonary sequelae following RSV infection in immunocompromised patients have not been adequately studied. Notably, however, RSV LRTI in the first 100 days following HSCT was associated with an increased risk of subsequent airflow decline in one study ${ }^{59}$ RSV LRTI has also been associated with a high risk for graft dysfunction and the development of bronchiolitis obliterans syndrome (BOS) in lung transplant recipients..$^{20,60,61}$

\section{Diagnosis}

One should hold a high clinical suspicion for RSV in the setting of lower respiratory tract disease and known circulation of RSV in the community, usually during the winter season. A laboratory diagnosis can be made by analysis of respiratory secretions (eg, nasal washing, BAL). Standard viral culture techniques in HEp-2 cells remain the gold standard, but RSV identification by these methods can take from 4 to 14 days. Rapid antigen assays are available, but these tests may lack sensitivity in adults. ${ }^{62}$ PCR-based assays can also be performed rapidly and are more sensitive. ${ }^{63}$ Testing for RSV is now typically included in multiplex PCR assays for a multitude of respiratory viruses.

\section{Prevention and Treatment}

Vaccine development for RSV and other paramyxoviruses has been hampered by the development of vaccine-associated pulmonary inflammation in early trials, and currently no licensed vaccines are available for clinical use. Palivizumab is a monoclonal RSV-specific antibody that was shown to reduce hospitalization rates among children at high risk for RSV infection in a multicenter, randomized, controlled trial ${ }^{64}$. In HSCT recipients, palivizumab appears to be safe and may be beneficial in the prevention and/or treatment of RSV infections ${ }^{65}$. However, further clinical trials are needed to determine its efficacy in preventing RSV infections in high-risk transplant recipients.

Although there is no consensus for a standard treatment algorithm for RSV, ribavirin is the mainstay in treatment algorithms for serious RSV infections. ${ }^{61}$ Ribavirin alone (orally or IV \pm inhaled ribavirin) has been associated with improved survival in HSCT recipients with RSV infection. ${ }^{66}$ Limited success has also been reported with inhaled ribavirin alone, ${ }^{12,65}$ inhaled ribavirin with intravenous immunoglobulin (IVIg) or RSV- specific immune globulin, ${ }^{14,67-69}$ and inhaled ribavirin with IV palivizumab. ${ }^{70,71}$ Unfortunately, all treatment studies of RSV have been plagued by lack of randomization or small sample sizes. 
A recent review has condensed all published data regarding outcomes of RSV infection. ${ }^{16}$ In this review, the authors found that ribavirin treatment, regardless of form, was associated with a much lower rate of progression from URI to LRTI when compared with no therapy. This was also true for mortality when patients with LRTI were treated. The addition of an immunomodulator (IVIg or RSV immune globulin) to inhaled ribavirin was associated with a trend for better outcomes than in patients treated with inhaled ribavirin alone. Until conclusive evidence is obtained from future clinical trials, the authors recommend that HSCT patients with RSV URI, and at least one risk factor for progression to LRTI, should be treated with either inhaled or oral ribavirin. Moreover, patients with RSV LRTI should be treated with combination therapy (IVIg or palivizumab) to reduce the risk of RSVassociated mortality. ${ }^{16}$

There are several new agents in early clinical trials for RSV. ALN-RSV01 (Alnylam Pharmaceuticals, Cambridge, MA) is a promising compound under development. This compound inhibits replication of RSV by interrupting synthesis of the viral nucleocapsid protein (N-protein). Phase 2 trials are under way. ${ }^{16}$

\section{PARAINFLUENZA}

\section{Epidemiology and Transmission}

Parainfluenza virus (PIV) is a single-stranded, enveloped RNA virus of the Paramyxoviridae family and may cause clinically significant disease in normal and immunocompromised hosts. ${ }^{72}$ There are four genetically distinct serotypes of parainfluenza: type 3 (PIV3), type 1 (PIV1), type 2 (PIV2), and type 4 (PIV4), in order of frequency isolated. The different serotypes vary in seasonality, prevalence, and clinical disease. PIV3 is found year-round with an increased incidence during spring and summer in areas where it is endemic, and it can be associated with bronchiolitis and pneumonia. ${ }^{73,74}$ PIV1 and PIV2 are found in epidemics, usually during the autumn/fall and winter and can result in childhood laryngotracheobronchitis (croup). ${ }^{73,74}$ Type 4 (PIV4) has not been well studied and is the least common serotype isolated.

PIV infects airway epithelial cells in children in whom infection is usually mild, ranging from the characteristic laryngotracheobronchitis to URI. However, bronchiolitis and pneumonia can also occur. LRTI typically affects only $15 \%$ of cases in infants and children. ${ }^{75}$ Adults can also be infected and transmit the disease. ${ }^{76}$ The primary sites of infection in children and adults are the mucous membranes of the nose and throat, and the incubation period ranges from 2 to 4 days. Distal spread of virus throughout the respiratory epithelium can be found within 1 to 3 days later. ${ }^{77}$

Typically transmission occurs from person to person, presumably through the transfer of secretions from the respiratory tract by direct contact or as large droplets. Reinfection can occur, but it usually results in mild illness. PIV, as with other respiratory viruses, may predispose to secondary bacterial infections via epithelial damage, impairment of ciliary function, and/or altering the normal host immune-inflammatory responses. In addition, bacterial infection may be promoted by increased expression of bacterial receptors on PIVinfected cells. ${ }^{78}$ 
With regard to HSCT two large retrospective studies performed at the University of Minnesota (1974 to 1990) and Fred Hutchinson Cancer Research Center (1990 to 1999) demonstrated that PIV respiratory infection was found in 27/1253 (2.2\%) and 253/3577 (7.1\%) HSCT; respectively. ${ }^{79,80}$ In the first study, of 27 patients with PIV, 12 (44\%) were adults and 15 (56\%) were children. ${ }^{79}$ Between both studies, 30 to $87 \%$ had limited URI, whereas 6 to $70 \%$ presented with simultaneous URI and LRTI. ${ }^{79,80}$ In other studies the frequency of LRTI due to PIV ranged between 23 and 58\%. ${ }^{51,81-84}$ Combined with more recent studies, the incidence of PIV infection post-HSCT, diagnosed by the standard methods of DFA and viral culture, varies from 2 to $9 \% .51,75,79-82,85$ However, new technologies used to detect PIV via PCR methods are demonstrating a higher incidence than previously reported. For instance one series demonstrated that up to $14 \%$ of HSCT recipients developed PIV, although this included asymptomatic cases. ${ }^{77}$ The median interval from transplantation to PIV infection ranges from 23 to 62 days..$^{79,80}$

The serotype most commonly isolated after HSCT is PIV3, accounting for 70 to $90 \%$ of cases, whereas PIV1 and PIV2 account for 7 to $11 \%$ and 4 to $14 \%$; respectively. ${ }^{79,80}$ PIV4 infection is rare (0.05 to 4\%). ${ }^{79,80}$ Most cases of PIV3 infection among HSCT recipients occur during the spring and summer months, when PIV3 infection peaks in the community; however, year-round occurrence is possible. ${ }^{79,86}$ The source of PIV infection is usually not apparent. Because PIV produces nonspecific symptoms in the immunocompromised and normal host, it may go unrecognized, rendering nosocomial transmission difficult to detect. ${ }^{87}$ Since reactivation without reinfection has not been confirmed, nosocomial transmission appears to be a mode of in-fection..$^{51,83,84,88}$ Hospital-acquired PIV infections, defined as those occurring 7 or more days after admission, accounted for more than $20 \%$ of PIV infections in a large HSCT population. ${ }^{80}$

Studies suggest that intense immunosuppression and lymphopenia may be the primary factors associated with PIV infection and pneumonia in HSCT recipients. Multivariable analysis identified the receipt of an unrelated transplant as the only risk factor for PIV acquisition. ${ }^{80}$ However, the dose of corticosteroids at the time of PIV infection acquisition was the primary factor associated with the development of PIV3 pneumonia, among both allogeneic and autologous HSCT recipi-ents. ${ }^{80}$ Yet another study of HSCT patients that received nonmyeloablative conditioning demonstrated a $35 \%$ cumulative probability of RVI at 18 months post-transplant, with PIV3 being the most frequently isolated organism (46\% of cases). ${ }^{89}$

Among SOT recipients, the majority of published data involve lung transplant recipients (LTRs). In one study of 93 LTRs who underwent serial BAL sampling with a Luminex xTAG Respiratory Viral Panel assay (Luminex Corporation, Austin, TX) that included PIV, 15 patients (16\%) had PIV; $12 / 15(80 \%)$ were asymptomatic. ${ }^{90}$ In another retrospective study of 454 LTRs from the University of Pittsburgh Medical Center between 1990 to 2000, PIV was found via culture and DFA in 24 (5\%) LTRs. The median time to diagnosis was 2.1 years; $20(83 \%)$ occurred more than 1 year after transplantation. ${ }^{91}$ PIV serotypes included PIV1 (29\%), PIV2 (8\%), and PIV3 (63\%). ${ }^{91}$ The incidence of PIV in other SOT recipients is not well studied. 


\section{Pathogenesis}

The primary sites of infection with PIV are the mucous membranes of the nose and throat; the incubation period ranges from 2 to 4 days. There is distal spread of virus throughout the respiratory epithelium that can be detected 1 to 3 days later. ${ }^{77}$ The extent of infection usually correlates with the severity of disease. For instance, mild URI is associated with limited infection of the nasopharynx, whereas more severe disease involves spread of infection to the lower respiratory airways. ${ }^{92,93}$ PIV1 and PIV2 usually infect the larynx and upper trachea and may cause croup. PIV3 is more associated with bronchiolitis and pneumonia and thus infects the distal airways. ${ }^{94}$ Interestingly, animal models have demonstrated that PIV can directly injure the airway epithelium. Importantly, these studies also suggest that indirect injury due to inflammatory mediators from the host immune response are more likely to be responsible for airway reactivity, bronchiolitis, and overall lung injury. ${ }^{94,95}$

\section{Clinical Presentation and Complications}

The clinical characteristics of PIV infection in the transplant population of patients are similar to those of infection with other respiratory virus such as RSV. Typical signs and symptoms of PIV infection in HSCT recipients include fever ( $<5$ to $89 \%$ ), cough (30 to $78 \%)$, coryza $(\sim 50 \%)$, watery eyes $(\sim 33 \%)$, sore throat ( 22\%), wheezing $(<10$ to $59 \%)$, sputum $(\sim 33 \%)$, dyspnea ( $<5$ to $47 \%)$, radiographic infiltrates $(\sim 60 \%)$, sinus headache $(\sim 15 \%)$, sinus congestion (30 to $45 \%$ ), sinus opacification ( $\sim 30 \%)$, and muscle aches $(<10 \%) .{ }^{79,83}$ Among HSCT recipients with LRTI due to PIV, the typical finding on highresolution chest computed tomography is multiple small nodules ( $<5 \mathrm{~mm}$ in diameter) without cavitations in a peribronchial distribution. ${ }^{96}$ However, these findings can be seen with other opportunistic infections. Radiographic infiltrates are also seen but usually suggest a late phase of the infection or coinfection/superinfection.

Risk factors for poor outcomes in HSCT recipients infected with PIV include sepsis/ multiorgan failure, pulmonary copathogens, and the need for mechanical ventilation. ${ }^{80,82,84}$ Coinfection with other respiratory pathogens is common in patients with PIV LRTI. ${ }^{80}$

Even PIV3 URI was associated with increased mortality in a large cohort of HSCT recipients; however, the association with mortality was greater in PIV3 LRTI. ${ }^{80}$ In fact, overall mortality from PIV3 LRTI was $35 \%$ at 30 days and $75 \%$ at 180 days after the diagnosis of pneumonia. ${ }^{80}$ Multiple other studies cited mortality rates associated with PIV3 infection ranging from 18 to 33\% $75,79-82,85,89$; PIV involvement of the LRT is associated with a further increase in mortality (eg, 46 to $75 \%) .{ }^{51,59,80,84}$

Progression of URI to LRTI is associated with the use of high-dose systemic steroids and lymphopenia. ${ }^{51,82}$ In a large retrospective study, the development of LRTI was driven primarily by the administration of corticosteroids for graft versus host disease (GVHD). ${ }^{80}$ These data suggest that tapering of corticosteroids at the time of PIV3 URI diagnosis may be one strategy to prevent progression to pneumonia.

Pulmonary sequelae are another significant complication of PIV infection in the HSCT population. In a large retrospective study involving 1131 HSCT recipients between 1990 and 
2000, 299 (26\%) developed airflow decline (defined as a >5\%/year decline in percentage of predicted forced expiratory volume in 1 second $\left(\mathrm{FEV}_{1}\right)$ during year 1 , with the year 1 $\mathrm{FEV}_{1}$ :-forced vital capacity (FVC) ratio $\left.<0.8\right) .{ }^{59}$ Among the 58 patients who developed PIV URI, 23 (40\%) developed airflow decline at 1 year. Seven patients developed PIV LRTI, of which six (68\%) developed airflow decline. Notably, these rates were higher than with RSV: 27 URI, of which seven (26\%) developed airflow decline, and 11 LRTI, of which six (55\%) developed airflow decline. ${ }^{59}$ The steepest decline in $\mathrm{FEV}_{1}$ occurred within 100 days of the infection; however; some patients continued to have progressive obstruction after 100 days. ${ }^{59}$

Among lung transplant recipients, the typical symptoms of PIV included cough (70\%), shortness of breath (SOB) (66\%), fever (17\%), infiltrates (24\%), and respiratory failure (20\%). ${ }^{91}$ Furthermore, PIV progression from URI to LRTI occurred in (13\%) of LTRs with PIV. ${ }^{90}$ Secondary bacterial infections (Pseudomonas and Staphylococcus) occurred in 3\% of the cases. ${ }^{91}$ Importantly, PIV is likely to be able to activate mediators of allograft rejection and allograft injury, which is supported by studies suggesting PIV can be associated with acute and chronic rejection. ${ }^{91,97}$ For instance, overall adverse outcomes (decline in FEV 1 or acute rejection) occurred in $26 \%$ of patients with PIV. ${ }^{90}$ The median time interval for allograft injury was 6 months. ${ }^{91}$ Although clinical data suggest a possible role for PIV in the development of allograft dysfunction and bronchiolitis obliterans syndrome (BOS), further studies are required. ${ }^{22,91,98,99}$ Notably, there are also reports of allograft rejection and injury associated with PIV infection in renal and liver transplant patients. ${ }^{100,101}$

\section{Diagnosis}

Nasopharyngeal aspirate and BAL samples can be sent for viral culture and DFA testing. NAT for detection of respiratory viruses is increasingly used to detect PIV and offers increased sensitivity for detection of PIV-3, with positive PCR demonstrated in DFAnegative subjects. ${ }^{102}$

\section{Prevention and Treatment}

Effective infection control procedures, including isolation of at-risk patients in the out- and in-patient clinical setting, should be enforced. ${ }^{84}$ Studies have identified close-contact transmission and surface contamination to be at least as important as droplet spread or direct hand contact in PIV transmission, and infectious virus has been demonstrated for up to 10 hours on skin and cloth. ${ }^{103,104}$

Presently there are no drugs licensed by the U.S. Food and Drug Administration for the treatment of PIV infection in children or adults. In the absence of robust clinical efficacy data from large randomized, controlled studies and with no licensed treatment available, some institutions offer ribavirin on the basis of evidence of in vitro and in vivo activity against parainfluenza viruses in case reports and small series. ${ }^{80,81,105}$ Sialic acid analogues, such as zanamivir, a 4-guanidino-Neu5Ac2en, designed to interfere with the binding of the viral hemagglutinin (HA) neuraminidase (NA) to host sialic acid residues (originally designed to inhibit influenza infections), are partially active inhibiting PIV3 in vitro ${ }^{106}$ but as of yet there is no evidence of in vivo activity. Similar drugs/compounds that block the 
hemagglutinin and neuraminidase (HA and NA) of PIV, such as BCX 2798 and BCX 2855, show promise, although human clinical trials are needed. ${ }^{107,108}$

\section{INFLUENZA}

\section{Epidemiology and Transmission}

Influenza is a common cause of respiratory infection in both immunocompetent and immunocompromised hosts, including SOT recipients. Although the majority of influenza infections are mild, worldwide, influenza remains a leading cause of death from infection due to seasonal epidemics and sporadic pandemics. The emergence and spread of zoonotic influenza strains, including avian and novel swine viruses, and globalization of the economy have placed the world's human populations at constant risk for an influenza pandemic.

Seasonal influenza infections occur during winter months, although cases during the 2009 H1N1 pandemic occurred year-round. An estimated 4 to 5\% of the general population is infected annually, although the actual incidence is difficult to determine because many mild cases go undetected. A similar incidence of influenza infection has been reported among transplant recipients, despite their immunocompromised state. Most reports in the literature are retrospective case series, and therefore, the frequency of influenza infections among transplant recipients is likely underestimated, whereas the severity of infection may be overrepresented due to many milder cases going unreported. They can occur at any time posttransplantation. The incidence is highest for recipients of HSCT and LTRs. Among HSCT recipients, reports from both the United States and Europe have generally described low rates of influenza infections, ${ }^{11,109-111}$ with allogeneic SCT recipients at higher risk of contracting influenza and other RVIs. ${ }^{11,109}$ A large analysis of HSCT recipients documented incidence of $1.3 \%$ during the first 120 days alone after transplantation. ${ }^{111}$ Not surprisingly, in this study, transplantation during influenza season was a significant risk factor for the development of influenza infection. Patients on higher doses of corticosteroids (i.e., $\geq 1$ $\mathrm{mg} / \mathrm{kg}$ ) and allogeneic transplant recipients have longer duration of viral shedding, raising the risk of transmission. ${ }^{111}$

Among SOT recipients, the incidence of influenza infection is highest in lung transplant recipients. ${ }^{112,113}$ A study analyzing cases of influenza infections in all adult SOT recipients at the University of Pittsburgh revealed 30 cases over a 10-year period, with 19 cases occurring among 454 LTRs, resulting in an incidence of 41.8 cases/1000 person years. ${ }^{114}$ In this study, five cases were reported among 1728 liver transplant recipients and six among 1387 renal transplant recipients, underscoring the relatively low incidence of influenza infections. Reports of frequency of influenza infections among SOT recipients from other centers have ranged from 0 to $13 \%$, with most reports describing incidences between 2 and $4 \% .{ }^{19,22,23,98,113,115-119}$ Limited studies of the 2009 H1N1 pandemic influenza have reported incidence rates of 3 to $5 \%$ among LTRs. ${ }^{120,121}$ However, although the overall incidence of influenza infection is low, influenza viruses still remain a common cause of RVI among transplant recipients. ${ }^{11,33}$ Furthermore, the rates of complications are higher among transplant recipients than the general population (see later discussion). 
Transmission of influenza occurs by infectious droplets that are spread directly by sneezing and coughing, or indirectly via fomites. Nosocomial transmission has been frequently reported, particularly on transplant units, highlighting the importance of infection control practices when caring for immunocompromised patients. ${ }^{122-124}$ Isolation precautions for droplets should be observed, with airborne precautions in cases of suspected pandemic strains. Transmission of influenza through transplantation of infected allografts has been reported, but such cases appear to be rare and mainly occur with lung transplantation. ${ }^{125,126}$ Guidelines from transplantation societies issued during the 2009 pandemic recommended that lungs should not be recovered for transplantation from donors with any influenza infection, and that small intestine should additionally not be recovered from donors with H1N1 pandemic influenza. Other organs can be considered for transplantation treatment with appropriate antiviral therapy. ${ }^{127,128}$ Direct transmission of influenza through renal and other solid organs has not been directly demonstrated, although renal allografts from acutely infected donors have been associated with delayed graft function. ${ }^{126}$ In addition, transmission of influenza can occur if the virus is present in the stem cell products, as has been reported during the $2009 \mathrm{H} 1 \mathrm{~N} 1$ pandemic. ${ }^{129}$

\section{Pathogenesis}

Influenza is a segmented, single-stranded, negative-sense RNA viruses. Influenza viruses are classified as type A, B, or C, with influenza A and B viruses being the major cause of human disease. Influenza A strains are further subtyped by their surface proteins, hemagglutinin (HA) and neuraminidase (NA), which are antigens that are sensed by the host immune system but also rapidly acquire mutations, enabling the virus to evade detection by prior humoral (i.e., antibody-mediated) immunity. Because of this antigenic drift, constant surveillance of circulating influenza strains is necessary to make appropriate alterations in vaccine composition on an annual basis. Pandemics arise when one of its seven genomic RNA segments reassorts with segment(s) from other influenza strains (eg, swine, avian, or human), resulting in antigenic shift. The 2009 H1N1 novel swine flu strain was thought to have arisen from reassortment event(s) between swine and triple-reassortant influenza strains. ${ }^{130-132}$

The portal of entry is the nose. Most cases of influenza infection are limited to the upper respiratory tract. Influenza viruses directly infect respiratory epithelial cells, causing localized injury and cell death. The antiviral immune response results in recruitment of cytotoxic CD8 + T lymphocytes and induction of proinflammatory cytokines such as TNF-a, IL-12, type I interferons (IFN- $\alpha$ and IFN $-\beta$ ), and IFN- $\gamma$. Occasionally, particularly in immunocompromised hosts, the infection spreads to the lower respiratory tract. An excess inflammatory response in the lung leads to lung injury, as has been described in cases of seasonal, pandemic, and avian influenza infections. Paradoxically, aspects of antiviral immunity appear to enhance the development of bacterial superinfections, resulting in secondary bacterial pneumonia, another serious complication of influenza and other viral infections. ${ }^{133,134}$

A significant number of lower respiratory tract influenza infections precipitate rejection of transplant allografts, including lung, kidney, and liver. ${ }^{114,135-138}$ Both acute rejection, as 
well as long-term rejection (i.e., BOS) has frequently been observed. The mechanisms by which this occurs are not entirely clear and are an area of intense investigation.

\section{Clinical Presentation and Complications}

Similar to immunocompetent hosts, most transplant recipients with influenza have mild, self-limited infections of the upper respiratory tract, although complications are common. ${ }^{136,137,139}$ In retrospective studies of HSCT recipients, 80 to $90 \%$ of patients with influenza present with URI and 10 to $20 \%$ with lower respiratory tract manifestations. ${ }^{11,110,111,139}$ Of the patients presenting with URI, $14 \%$ progressed to pneumonia within 14 days of onset. Lymphopenia was significantly associated with LRTI, although interestingly, steroid use appeared to be protective. The development of pneumonia was associated with increased 30-day mortality (28\%). ${ }^{111}$ Patients invariably have cough and rhinorrhea; fever may or may not be present due to immunosuppressed state or medications. ${ }^{11,110,111,139}$ Prolonged shedding of virus remains an issue, particularly among patients with lymphopenia. ${ }^{111,139}$

In solid organ recipients, influenza infections present most frequently with respiratory symptoms, including rhinitis, shortness of breath, and cough. ${ }^{12}$ Malaise and myalgia/ arthralgias are also common complaints. ${ }^{114}$ Unlike the pediatric transplant population, where virtually all patients present with fever, ${ }^{138,140}$ adult transplant recipients variably present with fever (50 to 80\%). ${ }^{113,114}$ However, the presence of fever in a transplant patient with suspected RVI strongly predicts influenza infection, ${ }^{113}$ although bacterial coinfection may be difficult to rule out.

Pediatric, lung, and HSC transplant recipients are at particular risk for complications of influenza infections. In the pediatric transplant population, a series of parainfluenza and influenza infections at the Children's Hospital of Pittsburgh reported that three out of 13 patients with influenza died from extensive lung injury; all were within 4 months of transplant (two liver, one heart transplant recipient), ${ }^{140}$ In another series of 12 pediatric SOT recipients with confirmed influenza B infections, five presented with LRTI, two with acute respiratory distress syndrome requiring mechanical ventilation, and five with evidence of neurological involvement, including one who died of cerebral herniation. ${ }^{138}$

In adults, a retrospective, single-center study in Switzerland of hospitalized patients during a 5-year period reported 33 cases of RVI, all of which occurred in immunocompromised individuals, with the largest group being LTRs (32\%), followed by BMT recipients (15\%). ${ }^{124}$ Thirty-nine percent of the cases of RVI were influenza. Crude mortality rate among the entire cohort was $24 \%$ at 30 days, with $50 \%$ of fatal cases having influenza as the pathogen. A high percentage of HSCT recipients hospitalized with influenza infection develop pneumonia (30 to 75\%), with reported mortality rates ranging from 13 to $43 \% .{ }^{111,122,141} \mathrm{Up}$ to half of HSCT patients with influenza-associated pneumonia have evidence of concomitant bacterial or fungal infections. ${ }^{33}$ Details about the complication rate in HSCT recipients following infection by $2009 \mathrm{H} 1 \mathrm{~N} 1$ pandemic influenza are just now starting to emerge, with some reports describing relatively similar rates of lower respiratory tract involvement as seasonal flu ${ }^{142-144}$ and others reporting markedly higher mortality rates and severity of illness. ${ }^{121,145}$ 
Complications from influenza infection in SOT recipients include LRTI or lung injury, acute and chronic rejection of the allograft, and coinfection with other pathogens. ${ }^{114}$ Among hospitalized SOT recipients with confirmed influenza infection, $47 \%$ developed LRTI and $17 \%$ developed bacterial pneumonia. Fifty to $60 \%$ of patients who underwent biopsy of the transplanted organ at the time of their illness demonstrated acute allograft rejection, ${ }^{112,114,119}$ suggesting that influenza infection may precipitate acute cellular rejection, similar to other respiratory viruses. During the $2009 \mathrm{H} 1 \mathrm{~N} 1$ pandemic, $23 \%$ of SOT patients (mainly renal) developed pneumonia, with $14 \%$ requiring intensive care. Overall mortality was $5 \% .{ }^{146}$

Although most transplant patients survive influenza infections, many develop long-term complications. The most significant complication in LTRs is chronic rejection or BOS. LTRs with influenza can experience significant decrease in $\mathrm{FEV}_{1}$, which persists for up to 6 to 12 months after the illness. ${ }^{147}$ Lower respiratory tract involvement increases risk of BOS. ${ }^{118}$ Influenza infection can precipitate BOS in lung transplant recipients who previously had no evidence of chronic rejection. Such cases have occurred shortly after the acute infection, with persistent decline in pulmonary function and/ or late acute allograft rejection. ${ }^{148,149}$

\section{Diagnosis}

Multiple microbiological techniques ${ }^{150}$ should be employed in the diagnosis of influenza viruses, particularly among patients with complicated infection. Virus culture, rapid antigen testing, and NAT (eg, PCR) are the tests of choice. If possible, nasopharyngeal swabs or washing should be sent for rapid antigen testing because this will yield the fastest results, although it is less sensitive. Hence, a negative antigen test does not reliably rule out influenza infection. Both viral culture and NAT tests are high sensitivity and can be sent on upper respiratory samples, but if there is lower respiratory involvement, BAL should be considered. ${ }^{151}$ In immunocompromised patients, PCR and other NAT tests are becoming the tests of choice for RVI given their high sensitivity. ${ }^{85,152}$ In addition, nucleic acid-based testing can determine subtype of influenza for epidemiological purposes. However, a caveat with NAT is that often multiple types of respiratory viruses are detected and may be positive in asymptomatic individuals, making it difficult to determine which virus is the true pathogen.

\section{Prevention and Treatment}

The influenza vaccine (trivalent inactivated subunit vaccine) is recommended for all transplant recipients, transplant candidates, their household contacts, and health care workers in contact with immunocompromised patients. ${ }^{153,154}$ However, both humoral and cellular immune responses to candidate antigens responses are attenuated in transplant recipients compared with normal controls. ${ }^{155,156}$ Because periods of augmented immunosuppression (such as with induction agents or cytolytic therapy) may decrease immunogenicity of vaccines, the timing of vaccination should be adjusted accordingly. ${ }^{61} \mathrm{In}$ HSCT recipients, vaccine responses are absent before 6 months posttransplant, and it is recommended to wait until 6 months to administer the vaccine. ${ }^{154}$ Similarly, in SOT recipients, vaccine can be administered any time after 3 to 6 months posttransplant. There 
are no data to support acute or chronic rejection as a consequence of vaccination in this population. The live attenuated intranasal preparation is not recommended for the immunocompromised population.

Available antiviral agents for the treatment of influenza fall into two classes, M2 inhibitors (amantidine and rimantidine) and neuraminidase inhibitors (oseltamivir and Zanamivir). Because of the emergence of resistance to M2-inhibitors, amantidine and rimantidine are not recommended for the treatment of influenza A or 2009 H1N1 viral infections. ${ }^{157}$ Hence, oral oseltamivir or inhaled zanamivir is the treatment of choice for influenza infections. Both agents have been shown in uncontrolled studies to be well tolerated and may prevent progressive disease in immunocompromised hosts. ${ }^{111,158,159}$ Controlled studies in transplant patients are lacking, and the optimal duration is not known at present. However, since transplant recipients often have prolonged duration of viral shedding, consideration should be given to extending duration of treatment to 10 to 14 days or until evidence of viral shedding ceases based upon weekly PCR testing. ${ }^{26,160}$

\section{ADENOVIRUS}

\section{Epidemiology and Transmission}

In the normal host, AdV infections are most frequently associated with self-limited URI (pharyngitis, coryza, etc.), gastrointestinal illness, or conjunctival disease. ${ }^{161}$ Adenoviruses have a worldwide distribution and have no significant seasonal variation. ${ }^{161}$ Severe and disseminated AdV infections, although rare in the immunocompetent host, ${ }^{162,163}$ can occur in immunocompromised patients. ${ }^{164-175}$ Augmented immunosuppression, including exposure to cytolytic therapies, is considered to be a risk factor for more severe disease in patients who experience $\mathrm{AdV}$ infection. ${ }^{161}$

AdV infections are typically caused by exposure to infected respiratory secretions through person-to-person contact. ${ }^{176,177}$ Transmission occurs via inhalation of aerosolized droplets, direct conjunctival inoculation, fecal-oral spread, or exposure to infected tissue or blood. ${ }^{177-179}$ The incubation period ranges from 2 to 14 days. ${ }^{177}$ Donor organ-associated transmission of AdV has been described. ${ }^{180} \mathrm{AdV}$ may also establish latency in lymphoid or other tissues, and reactivation can occur after initiation of immune suppression. ${ }^{181-183}$

AdV has increasingly been recognized as a pathogen in patients following HSCT. The highest risk period for AdV infection is within the first 100 days after transplant. ${ }^{184}$ Among HSCT recipients, children have a higher incidence of AdV infection (23 to 26\%) than adults (9\%). ${ }^{185}$ Additional risk factors among HSCT recipients include allogeneic HSCT, ${ }^{184,186}$ HLA (human leukocyte antigen) mismatch, ${ }^{184,187}$ severe T cell depletion, ${ }^{184,188}$ and GVHD. ${ }^{177,186,188-193}$

Among SOT recipients, risk factors for AdV infections include pediatric recipients, ${ }^{184,194}$ receipt of antilymphocyte antibodies, ${ }^{184}$ and AdV serological mismatch (donor-positive/ recipient-negative). ${ }^{184}$ In a prospective surveillance study of SOT recipients, AdV viremia was detected in $7.2 \%$ of patients during the first posttransplant year, including $8.3 \%$ of liver recipients (10/121), $6.5 \%$ of kidney recipients, and $6.7 \%$ of heart recipients. ${ }^{195}$ The majority 
(58\%) of these patients had no symptoms, and all patients recovered spontaneously. In contrast, other retrospective studies reported serious infections and poor outcomes in SOT recipients. In a review of 484 pediatric liver transplant recipients, 49 (10\%) developed AdV infections and nine deaths were attributed to AdV disease. ${ }^{194}$ In another review of 191 adult liver transplant recipients, 11 (5.8\%) were diagnosed with AdV infection, and there were two AdV-related deaths. ${ }^{196}$ In pediatric heart transplant recipients, the presence of AdV DNA in cardiac biopsies was associated with poor graft survival. ${ }^{197} \mathrm{AdV}$ has also been associated with hemorrhagic cystitis and graft dysfunction in adult renal transplant recipients. ${ }^{198,199}$

In a molecular surveillance study of LTRs using PCR, 22.5\% (18/80) of patients developed AdV viremia in the first year posttransplant, but most (78\%) were asymptomatic. ${ }^{200}$ All recovered spontaneously, and there was no association with subsequent allograft rejection or dysfunction noted. Severe adenoviral infections after lung transplantation are less common but have been associated with graft dysfunction and fatal disease. In a review of 383 LTRs, four (1.3\%) were diagnosed with AdV infections, including 3/40 (8\%) pediatric recipients and $1 / 268(0.4 \%)$ adult recipients. All four developed severe necrotizing pneumonia and all died within 45 days of transplant. ${ }^{117}$ In another study of 19 pediatric LTRs, AdV infections were diagnosed in eight, resulting in two early deaths, as well as late graft loss and obliterative bronchiolitis (OB). ${ }^{201} \mathrm{~A}$ case of fatal AdV pneumonia in an adult LTR 4 years after transplant was described. ${ }^{202}$

\section{Pathogenesis}

Fifty-three serotypes and seven species (A through G) of AdV are recognized. ${ }^{203-205}$ However, only one third of serotypes are associated with human disease. ${ }^{176,203,206-210}$ Globally, serotypes 1 through 4, 7, and 21 are most commonly associated with human disease. ${ }^{176,207-210}$ Different serotypes display different tissue trophisms and correlate with clinical manifestations of infection (discussed in Adenovirus article in this issue). ${ }^{176,177,203,205}$

Ineffective cellular immunity is a risk factor for $\mathrm{AdV}$ infection, and $\mathrm{T}$ cell-mediated immunity is important for recovery. ${ }^{184}$ Increases in lymphocyte counts or CD4 counts were associated with clearance of AdV infection ${ }^{211,212}$ and improved survival. ${ }^{212,213}$

The humoral response also plays an important role in controlling AdV infection. Serotypespecific neutralizing antibodies correlate with clearance of AdV. ${ }^{184,212}$ Patients whose viremia cleared exhibited an increased humoral response, with eight- to 16 -fold increase in serotype-specific antibodies. ${ }^{212}$

\section{Clinical Presentation and Complications}

Clinical manifestations in immunocompromised patients include pneumonia, hepatitis, hemorrhagic cystitis, colitis, pancreatitis, meningoencephalitis, and disseminated disease, depending on the underlying disease, affected organ system, patient age, and virus serotype. ${ }^{184}$ Among SOT recipients, the transplanted organ is the most common site of disease. ${ }^{184}$ The spectrum of AdV-associated syndromes is broad in part due to the various 
serotypes (discussed elsewhere in this issue). In immunocompromised patients, AdV infections tend to be more prolonged, more severe, and sometimes fatal.

\section{Diagnosis}

Multiple approaches are available to diagnose AdV infection. Conventional viral culture is the most sensitive and specific method and usually yields a characteristic cytopathic effect in 2 to 7 days, but occasionally may take up to 21 days for some serotypes. ${ }^{177}$ Shell vial culture techniques have improved the speed of diagnosis compared with conventional culture. ${ }^{214}$ Viral antigen assays can provide the most rapid diagnosis, but the sensitivity of these tests is limited. ${ }^{215}$ PCR techniques for AdV in plasma, urine, and other infected fluids or tissues are highly sensitive. ${ }^{177,216,217}$ Among transplant recipients, PCR assays from blood and stool samples may be an effective way to screen asymptomatic patients and facilitate early "preemptive" therapy. ${ }^{176,190,195,218}$ However, the role of routine surveillance is controversial. ${ }^{177}$ Further, PCR quantification of viral load has been used to monitor response to therapy. 216,219

AdV can also cause characteristic intranuclear inclusions that can be seen on biopsy. ${ }^{177}$ Occasionally AdV inclusions may be confused with CMV inclusions, but AdV-specific immunohistochemical stains are available. ${ }^{220}$

\section{Prevention and Treatment}

Currently, there is no clinically available AdV vaccine. Given the potential for nosocomial spread, infection control measures are critical in transplant clinics and inpatient units. Notably, hand washing may not reliably remove AdV from contaminated fingers. ${ }^{221}$ Outbreaks have been controlled by cohorting patients; using gloves, gowns, and goggles; and excluding symptomatic staff from the unit. ${ }^{222}$

With regard to treatment of established AdV infection, prospective trials are lacking, and no antiviral drug has been approved to treat AdV. ${ }^{184}$ Ganciclovir, ribavirin, and vidarabine each have limited in vitro activity against $\mathrm{AdV} .{ }^{223-225}$ Case reports and small series have reported successful outcomes with each treatment, but it is impossible to determine whether these patients would have recovered without therapy. ${ }^{226}$

Cidofovir (CDV), a cytosine nucleotide analogue that inhibits DNA polymerase, has the greatest in vitro activity against $\mathrm{AdV}^{223,227,228}$ and is the preferred therapeutic agent. ${ }^{177}$ $\mathrm{CDV}$ is available only intravenously, ${ }^{177}$ but based upon its pharmacokinetic properties it can be dosed once weekly. The most common dosing regimen is $5 \mathrm{mg} / \mathrm{kg}$ weekly, ${ }^{184,218}$ but other dosing regimens have been reported, including $1 \mathrm{mg} / \mathrm{kg}$ thrice weekly in children. ${ }^{229}$ The duration of therapy depends upon clinical response. In the largest published series, 20/29 (69\%) HSCT patients treated with CDV cleared their AdV infection. ${ }^{230}$ In multiple other smaller series of AdV infected HSCT recipients with variable presentations, most improve with CDV treatment. ${ }^{187,231,232}$

Although CDV is generally well tolerated, ${ }^{190,218}$ the potential for nephrotoxicity, especially when used in combination with other nephrotoxic drugs, can be problematic. ${ }^{177,184}$ 
Hydration and probenacid may minimize nephrotoxicity, ${ }^{177,190,233,234}$ but careful monitoring of renal function is critical.

Because T cell immunity plays a critical role in controlling AdV infection, ${ }^{184}$ the level of immunosuppression should be reduced when feasible. ${ }^{89,190,220}$ However, there is also some evidence for the use of immunotherapy in immunosuppressed patients, primarily HSCT recipients. Small series of adoptive transfer of virus-specific lymphocytes in pediatric HSCT recipients reported positive outcomes. ${ }^{235,236}$ Pooled IVIg has been commonly used as adjunctive therapy to CDV and other antiviral medications, but data are insufficient to assess efficacy. ${ }^{191}$

Importantly, not all patients with AdV infections or viremia require treatment. ${ }^{177,209}$ Most patients are asymptomatic at the time of viremia, and spontaneous resolution is common. ${ }^{195,209}$ We reserve treatment for symptomatic patients or those with dissemination. "Preemptive" therapy may have a role in viremic but asymptomatic organ transplant recipients at high risk for dissemination. Prospective, randomized trials are needed to elucidate indications for therapy in both symptomatic and asymptomatic patients with AdV infections.

\section{HUMAN METAPNEUMOVIRUS}

\section{Epidemiology and Transmission}

Human metapneumovirus $(\mathrm{HMpV})$ is a paramyxovirus most closely related to RSV that is nearly universally encountered by 5 to 10 years of age. ${ }^{237}$ It is second only to RSV as a cause of bronchiolitis in children and as an etiology of LRTI in hospitalized children. 238 $\mathrm{HMpV}$ circulates year-round, but in temperate climates it is found more often in late winter and spring. ${ }^{239}$ The virus was first described in 2001 by van den Hoogen et al in respiratory samples of children presenting with a clinical syndrome compatible with RSV. ${ }^{237}$

$\mathrm{HMpV}$ can cause severe disease in both normal and immunocompromised populations. In a survey of 30 infants intubated with RSV bronchiolitis who underwent BAL, 70\% were coinfected with $\mathrm{HMpV}$ as detected by PCR. Importantly, of the infants with no underlying risk factor for severe RSV disease, $90 \%$ were coinfected with $\mathrm{HMpV}$, suggesting that $\mathrm{HMpV}$ can cause or coprecipitate severe disease in a nonimmunocompromised population. ${ }^{240}$ In patients hospitalized for HSCT or hematologic cancer, $3.2 \%$ of the patients were positive for $\mathrm{HMpV}$ ( $4.5 \%$ of children) and $55 \%$ of the patients had evidence of infiltrates on chest radiographs. ${ }^{241}$ In a 3-year retrospective study of 249 samples from 163 patients with HSCT, 11 had HMpV by PCR, three (27\%) of whom had radiographic evidence of pneumonia and HMpV on BAL. One patient died from sepsis but was coinfected with influenza B. ${ }^{239}$ Of 89 LTRs who had URI or LRTI symptoms, $31 \%$ had virus detected by PCR, of which 31\% (19) were HMpV, which was a much higher percentage of $\mathrm{HMpV}$ than other studies. ${ }^{60}$ No patient required intubation, but $63 \%$ of the patients with $\mathrm{HMpV}$ required hospitalization for acute allograft dysfunction. A survey of outpatient LTRs found that $51 \%$ of 388 patients had symptoms of either URI or LRTI, and $3.6 \%$ of BAL and nasopharyngeal swabs were positive for a respiratory virus by PCR. HMpV represented $18 \%$ (6) of the positive samples. ${ }^{23}$ Garbino et al noted that $4 \%$ of lung 
transplant BAL samples positive for respiratory virus had $\mathrm{HMpV} .{ }^{242}$ In a 2-year survey of 60 LTRs, Weinberg found 112 episodes of respiratory infection, and 51 of these episodes had at least one respiratory virus detected by PCR. Seven $(6 \%)$ had $\mathrm{HMpV}$, of which four (3\%) were sole pathogens. $\mathrm{HMpV}$ infections requiring hospitalization occurred at rates similar to PIV and RSV, but clinically diagnosed acute rejection (i.e., no biopsy), was more often seen in RSV than HMpV. ${ }^{119}$ Not all studies have found HMpV to cause severe disease. Moreover, detection of viral nucleic acid alone does not signify disease, a situation that is more likely the case in "surveillance" bronchoscopies after lung transplantation. As an example, of 93 LTRs undergoing 582 BALs (72\% for surveillance) the 13\% of BAL that were positive for any respiratory virus were three times as likely to come from asymptomatic versus symptomatic patients. All four $\mathrm{HMpV}$ cases were from asymptomatic hosts. ${ }^{90}$

\section{Clinical Presentation and Complications}

The presentation of $\mathrm{HMpV}$ is generally that of a URI, yet fever, cough, dyspnea, pneumonia, and wheezing have been reported frequently ${ }^{243,244}$ and are more common in immunocompromised individuals. ${ }^{243,245}$ Wheezing may be less frequent in patients with $\mathrm{HMpV}$ as compared with patients who have RSV. ${ }^{60}$ In a 6-year study to identify HMpV symptoms in adult HSCT patients, 769 respiratory samples were examined for $\mathrm{HMpV}$ infection by PCR. Only $2.5 \%$ (19) were positive, and three of those were coinfected with another virus. Seventy-two percent of the patients had URI only, whereas the remainder had evidence of pneumonia, none of whom died. ${ }^{246}$ In at least one instance $\mathrm{HMpV}$ has been detected in lung tissue by in situ hybridization from an open lung biopsy. ${ }^{243}$ An unusual presentation of URI and meningoencephalitis, similar to Nipah virus, another paramyxovirus, in a 14-month-old boy was associated with $\mathrm{HMpV}$ in lung and brain tissue by PCR, but not by histopathology. ${ }^{247}$ Given that $\mathrm{HMpV}$ can be a severe illness, particularly in the immunocompromised, is it possible to predict who will develop severe disease? Using samples from an HSCT population, Campbell found seven patients with HMpV by PCR.

Although quantitative viral load was not associated with the need for mechanical ventilation or death, detection of viral nucleic acid (not specifically $\mathrm{HMpV}$ ) in the serum was significantly associated with death. ${ }^{248}$

\section{Diagnosis}

As with most viruses, comparison of the diagnostic sensitivity of culture, immunofluorescence, and PCR demonstrates PCR to be the most sensitive. ${ }^{245}$ A study of HSCT patients included HMpV in such a comparison and not unexpectedly found that PCR was twice as sensitive as culture and four times more sensitive than immunofluorescence. However, detection by PCR alone was associated with lower viral load and fewer respiratory symptoms ${ }^{85}$ Serological determination of exposure is also possible. ${ }^{249}$

\section{Treatment}

Ribavirin has been used for treatment in at least one published study, ${ }^{60}$ and both ribavirin and IVIg appear to have near equal efficacy against $\mathrm{HMpV}$ in vitro. ${ }^{250,251}$ Reduction of steroid doses may also be of a more general benefit in at least reducing the chance of infection with respiratory viruses. ${ }^{245}$ 


\section{CORONA VIRUS}

\section{Epidemiology and Transmission}

The human coronavirus $(\mathrm{HCoV})$ is associated with URI as one of the "common cold" viruses and may also cause bronchiolitis and croup in children. ${ }^{252}$ It is an RNA virus of the Coronaviridae family. ${ }^{252}$ There are presently four genotypes of non-SARS HCoV identified: OC43, ${ }^{253} 229 \mathrm{E},{ }^{254} \mathrm{HKU} 1,{ }^{255}$ and NL63. ${ }^{256,257}$ All four genotypes have been found in upper and lower respiratory tracts of immunocompromised patients. In temperate zones the virus may have a predilection for winter transmission, but there is little evidence for seasonal transmission of $\mathrm{HCoV} .{ }^{252,258}$ In a prospective evaluation of adults hospitalized for an acute respiratory illness, $540 \mathrm{BAL}$ from 279 patients were assessed for HCoV. ${ }^{259}$ They found $29 \mathrm{BAL}$ with $\mathrm{HCoV}$ (28 from SOT recipients and 14 from patients with hematologic cancer), of which OC43 was the most prevalent (12), then 229E (7), NL63 (6), and finally HKU1 (4). In 522 BAL from 299 patients respiratory virus nucleic acid was found in $17.4 \%$, of which $32 \%$ was HCoV. ${ }^{242}$ A survey of respiratory virus infections in adult LTRs found that $\mathrm{HCoV}$ accounted for $15 \%$ of the viruses detected in either BAL or nasopharyngeal swab, ${ }^{23}$ whereas in $82 \mathrm{HSCT}$ patients, four of $85 \mathrm{BAL}$ samples (5\%) were found to have $\mathrm{HCoV} .248$

\section{Clinical Presentation and Complications}

There are limited data regarding the clinical presentation of the virus in immunocompromised hosts, outside of URI. In one study of LTRs, $73 \%$ of the HCoV from BAL were from asymptomatic patients, but $72 \%$ of the bronchoscopies were for surveillance. ${ }^{90}$ Milano performed a year-long survey of weekly respiratory symptoms and viral detection by PCR in respiratory samples for the first 100 days after HSCT. ${ }^{258}$ By day 100 the cumulative incidence of $\mathrm{HCoV}$ was $11 \%$, and $40 \%$ of these patients were asymptomatic at the time the virus was identified. None of the 13 patients with $\mathrm{HCoV}$ and URI symptoms developed LRTI in the first 100 days. Three of 22 persons with HCoV shed viral nucleic acid for at least 3 months. Isolation of $\mathrm{HCoV}$ was not statistically associated with any symptoms by regression analysis. There are two case reports of severe disease, the first being of an HCoV LRTI shortly after treatment for a solid tumor. ${ }^{260}$ The second is of an immunocompromised adult after HSCT who developed an URI with HCoV NL63 and who ultimately died of progressive respiratory failure without identification of other pathogens. $^{261}$

\section{Diagnosis}

Diagnosis of $\mathrm{HCoV}$ is made by PCR, and $\mathrm{HCoV}$ is now included in multiplex PCR assays for a multitude of respiratory viruses.

\section{Treatment}

There is no specific treatment. 


\section{RHINOVIRUS}

\section{Epidemiology and Transmission}

Human rhinovirus (HRV) is a picornavirus and is the most prevalent common cold virus with a peak incidence in the early fall. ${ }^{262}$ There are three recognized genotypes, A, B, and C, which circulate year round. ${ }^{258,263}$ This virus is ubiquitous, and it is estimated that each year every adult has one HRV infection. ${ }^{262}$ One study found that of 346 adults with cold symptoms $82 \%$ had picornavirus infections. ${ }^{262} \mathrm{HRV}$ is generally the most commonly isolated respiratory virus in HSCT and LTRs..$^{23,152,242,245,264}$ For example, of 299 patients who underwent a combined $522 \mathrm{BAL}, 17 \%$ had respiratory viral nucleic acid detected by PCR, with $23 \%$ of these being HRV, the most prevalent of all viruses tested for. ${ }^{242}$ Furthermore, a multicenter study of respiratory viruses in pediatric LTRs found that $22 \%$ of infections were due to HRV. ${ }^{263}$

\section{Clinical Presentation and Complications}

The clinical presentation of HRV is generally that of a URI; coryza and cough. In most studies HRV is not associated with severe disease, though reports of severe and even fatal disease possibly attributable to HRV exist. ${ }^{265,266}$ Indeed, adult LTRs with HRV detected on BAL were more likely to be asymptomatic than symptomatic (37 vs 9). ${ }^{90}$ Liu found 14 of 28 respiratory viruses in pediatric LTRs were HRV, and there were no associated deaths or subsequent BOS occurrences. ${ }^{267}$ In a pediatric bone marrow unit $82 \%$ of the 11 patients with HRV detected by nasopharyngeal aspirate were either asymptomatic or with coryza without LRTI, and all survived. ${ }^{268}$ No association of HRV with LRTI was found in a study of 159 BAL from 88 immunocompromised patients, including LTRs. ${ }^{269}$ However, the degree of immunosuppression influences the likelihood of developing LRTI. A retrospective cohort study evaluated the effect of RVI, including HRV, on patients undergoing nonmyeloablative versus myeloablative chemotherapy versus auto-HSCT patients. The incidence of any RVI was statistically less in the auto-HSCT, but LRTI was less common in nonmyeloablative versus the other two more immunocompromised groups ${ }^{51}$ Looking only at enterovirus and HRV in patients with hematologic malignancies, $15 \mathrm{HRV}$ were found by PCR, and four of the 15 had signs of LRTI. Two of these patients developed LRTI subsequent to URI. However, one-half of the HRV LRTI cases were associated with coinfection by organisms known to cause LRTI. There were no deaths associated with HRV. ${ }^{270}$ Another study in HSCT patients in the first 100 days post-HSCT found HRV in $22 \%$ of patients. In $87 \%$ of HRV-positive patients coryza and cough was present, with three patients progressing to LRTI. ${ }^{258}$ Prolonged shedding of HRV in immunocompromised patients does occur. In the aforementioned study of HSCT patients the median shedding time of HRV was 3 weeks, whereas over $10 \%$ shed for more than 3 months. ${ }^{258}$ In a small study of adult LTRs, three of 11 cases had prolonged shedding of HRV, one for more than 18 months. ${ }^{271}$

Given that this most common of respiratory viruses can progress to LRTI in the most vulnerable patients, can severe disease be predicted by the viral load of HRV? Gerna et al looked at immunocompromised children (HSCT recipients) and adults (LTRs), and normal children and adults and found that immunocompromised adults tended to have lower PCR 
counts and be asymptomatic, whereas immunologically normal children had higher viral loads associated with more severe disease. ${ }^{272}$ Overall, viral loads $>10(5)$ were associated with LRTI. The indirect effects of this most common of respiratory pathogens on acute and chronic rejection have been assessed by Costa et al, ${ }^{273}$ who found no effect in 18 LTRs. Although not specifically HRV, at least one report does suggest an association of RVI with subsequent acute and chronic rejection. ${ }^{147}$

\section{Diagnosis}

Detection of viral nucleic acid by PCR is the most sensitive method, ${ }^{85}$ but culture and DFA are also possible, albeit with lower sensitivity.

\section{Treatment}

There is presently no licensed specific treatment, but IVIg has been used in severe cases along with reduction of steroid immunosuppression. Pleconaril has an efficacy of $70 \%$ for treatment of HRV and was submitted for FDA consideration in 2001 but rejected secondary to safety concerns; it is presently not licensed in the United States. ${ }^{274}$ In prelicensing trials pleconaril reduced the duration of symptoms by an average of 1 day, and coryza was significantly improved compared with placebo by the second day. ${ }^{274}$

\section{BOCAVIRUS}

\section{Epidemiology and Transmission}

This newly described parvovirus, human bocavirus ( $\mathrm{HBoV})$, was discovered by Allander et al in 2005 using universal viral PCR primers on respiratory samples from which no other pathogens had been identified. ${ }^{275}$ At the time of discovery, the authors performed a small epidemiological study and found that 17 children admitted to the hospital with URI and wheezing had HBoV detected by PCR in upper respiratory samples. Of these 17 children, 14 had no other viral pathogens identified on the same respiratory samples, but a broad PCR based approach to identifying coinfections was not undertaken. ${ }^{275}$ The incidence of HBoV varies but is $\sim 4.5 \%$ in children with URI. ${ }^{276}$ Like other parvoviruses of humans and animals, the virus is found in respiratory secretions and is likely transmitted via respiratory droplets. ${ }^{277}$ However, dissemination of HBoV has been described in the plasma and stool, thus passage via other bodily fluids cannot yet be excluded. ${ }^{276,278,279}$ There does not appear to be a strong seasonality with $\mathrm{HBoV}$, and it can be found year around. 276,280

The majority of studies have used detection of HBoV by PCR in the nasopharynx of children, with few sampling the "lower respiratory tract" by BAL and even fewer assessing carriage in transplant patients. Garbino et al did assess 522 BAL samples from 299 patients for respiratory viruses by PCR. ${ }^{242} \mathrm{HBoV}$ was the least frequently detected virus at a frequency of 3\%. Another study of 341 BAL samples over a year and a half found negligible differences in $\mathrm{HBoV}$ detection rates between SOT, HSCT, and nontransplant patients. All samples with HBoV did have clinical symptoms of LRTI, yet all but one HBoV sample had another significant respiratory pathogen at the time of clinical presentation. ${ }^{269}$ In an Australian study of 153 BAL samples from 120 patients, including LTRs, no HBoV DNA was detected in any patient. ${ }^{281}$ 


\section{Clinical Presentation and Complications}

The clinical presentation of $\mathrm{HBoV}$ is presently not well defined but may include fever, URI, wheezing, LRTI, and diarrhea. An early report by Schenk et al noted disseminated HBoV infection in a 4-year-old child after allogeneic HSCT transplant who had developed a nonspecific febrile episode. ${ }^{279}$ The patient had HBoV DNA detected in the nasopharynx, blood, and stool on multiple occasions both pre- and postengraftment. The report merely highlights the fact that the virus may disseminate in immunocompromised individuals without a clear syndrome. Indeed, dissemination of HBoV may be more the rule than the exception. ${ }^{276}$ A prospective collection of 1200 nasopharyngeal and 1435 fecal samples from children and young adults with acute gastroenteritis and negative screening for common respiratory viruses detected $\mathrm{HBoV}$ in $7 \%$ of nasopharyngeal and $2 \%$ of fecal samples. ${ }^{280}$ Watery diarrhea and fever were the most common symptoms in those with $\mathrm{HBoV}$ in the stool. However, $33 \%$ of nasopharyngeal and $56 \%$ of fecal samples were coinfected with another potential pathogen, making it difficult to ascribe the clinical findings to $\mathrm{HBoV}$ alone. ${ }^{280}$ Similarly, Vicente et al found $\mathrm{HBoV}$ in $9 \%$ of 527 fecal samples from children with acute gastroenteritis and in $8 \%$ of respiratory samples from children with symptoms of URI. ${ }^{278}$ As with other studies, $63 \%$ of these respiratory samples had coinfection with another respiratory virus, whereas in 58\% of the fecal samples additional pathogens were identified. ${ }^{278}$ At least one study suggests a more serious clinical presentation is possible. In 335 children over 7 years of age most children with $\mathrm{HBoV}$ presented with bronchiolitis or bronchopneumonia with about half of the cases being coinfected with another respiratory virus. $^{276}$

Similar rates of HBoV DNA isolation between cases and controls are commonly found in surveillance studies, ${ }^{282,283}$ and HBoV DNA in the nasopharynx is alone not likely to be sufficient for diagnosis of $\mathrm{HBoV}$ disease. As with the related parvovirus B19, it may take time to figure out exactly what role $\mathrm{HBoV}$ has in different clinical syndromes. B19 is also often found in respiratory secretions, but it does not cause respiratory disease. ${ }^{277}$ Furthermore, closely related parvoviruses of animals tend to cause nonrespiratory diseases. ${ }^{284}$ Thus, at this time it is difficult to speak with certainty regarding clinical syndromes attributable to this newly described human parvovirus.

\section{Diagnosis}

Diagnosis is based upon the presence of HBoV DNA by PCR or by rise in IgM and IgG antibody titers. ${ }^{285}$

\section{Treatment}

There is no specific treatment.

\section{IMPACT OF RESPIRATORY VIRAL INFECTIONS ON CHRONIC LUNG ALLOGRAFT DYSFUNCTION}

Respiratory viruses are increasingly being recognized as a significant risk factor for development of BOS. ${ }^{19,23,90,147}$ OB, the histopathological hallmark of chronic lung allograft rejection, is a fibroproliferative small airways disease thought to be preceded by 
inflammation, epithelial injury, and mucosal ulcerations. Clinically, OB manifests as progressive airflow limitation and dysfunction of the lung allograft (BOS) leading to respiratory disability and ultimately death. The development of BOS is the most important factor limiting the long-term survival after lung transplantation with $\sim 50 \%$ of patients affected within 5 years of transplantation. ${ }^{286}$ Notably, chronic pulmonary GVHD after HSCT may also produce progressive airflow decline, and the risk for this syndrome is also increased following RVI. ${ }^{59}$

In addition to epidemiological studies, preclinical models have also suggested that RVI may potentiate rejection. Viral infection caused rejection of skin allografts in otherwise tolerant hosts. ${ }^{287}$ Winter et al demonstrated that murine Sendai virus, which is closely related to human parainfluenza-1, augmented the airway damage in allogeneic but not syngeneic or nontransplanted rat lung allografts. ${ }^{288}$ Subsequent studies in a murine orthotopic tracheal transplant model of obliterative airways disease demonstrated increased airway fibrosis in allografts infected with Sendai virus. ${ }^{289}$ Further research is needed to delineate the immune mechanisms that contribute to postviral chronic allograft dysfunction in lung transplant recipients.

\section{SUMMARY}

The importance of RVI continues to gain recognition in HSCT and SOT recipients, and our understanding continues to evolve. Due to chronic immune suppression, these patients are particularly susceptible to severe disease that is uncommon in the general population. We now also recognize that RVI may have important indirect consequences, including coinfection and potentiation of lung allograft rejection. Newer molecular techniques allow for rapid identification and identification of a greater number of viruses. However, the significance of our ability to detect RVI in transplant recipients, many of whom have minimal or no symptoms, remains to be determined. Importantly, treatment options for most RVI are limited. Prevention of infection with infection control measures and immunization against pathogens for which vaccines are available is important.

\section{REFERENCES}

1. Hall CB, Weinberg GA, Iwane MK, et al. The burden of respiratory syncytial virus infection in young children. N Engl J Med. 2009; 360(6):588-598. [PubMed: 19196675]

2. Falsey AR, Hennessey PA, Formica MA, Cox C, Walsh EE. Respiratory syncytial virus infection in elderly and highrisk adults. N Engl J Med. 2005; 352(17):1749-1759. [PubMed: 15858184]

3. Boyce TG, Mellen BG, Mitchel EF Jr, Wright PF, Griffin MR. Rates of hospitalization for respiratory syncytial virus infection among children in Medicaid. J Pediatr. 2000; 137(6):865-870. [PubMed: 11113845]

4. Wang EE, Law BJ, Boucher FD, et al. Pediatric Investigators Collaborative Network on Infections in Canada (PICNIC) study of admission and management variation in patients hospitalized with respiratory syncytial viral lower respiratory tract infection. J Pediatr. 1996; 129(3):390-395. [PubMed: 8804328]

5. Duncan CB, Walsh EE, Peterson DR, Lee FE, Falsey AR. Risk factors for respiratory failure associated with respiratory syncytial virus infection in adults. J Infect Dis. 2009; 200(8):1242-1246. [PubMed: 19758094] 
6. El Saleeby CM, Somes GW, DeVincenzo JP, Gaur AH. Risk factors for severe respiratory syncytial virus disease in children with cancer: the importance of lymphopenia and young age. Pediatrics. 2008; 121(2):235-243. [PubMed: 18245413]

7. Hall CB, Powell KR, MacDonald NE, et al. Respiratory syncytial viral infection in children with compromised immune function. N Engl J Med. 1986; 315(2):77-81. [PubMed: 3724802]

8. King JC Jr, Burke AR, Clemens JD, et al. Respiratory syncytial virus illnesses in human immunodeficiency virus-and noninfected children. Pediatr Infect Dis J. 1993; 12(9):733-739. [PubMed: 8414800]

9. Milner ME, de la Monte SM, Hutchins GM. Fatal respiratory syncytial virus infection in severe combined immunodeficiency syndrome. Am J Dis Child. 1985; 139(11):1111-1114. [PubMed: 3877455]

10. Chemaly RF, Ghosh S, Bodey GP, et al. Respiratory viral infections in adults with hematologic malignancies and human stem cell transplantation recipients: a retrospective study at a major cancer center. Medicine (Baltimore). 2006; 85(5):278-287. [PubMed: 16974212]

11. Ljungman $\mathrm{P}$, Ward KN, Crooks BN, et al. Respiratory virus infections after stem cell transplantation: a prospective study from the Infectious Diseases Working Party of the European Group for Blood and Marrow Transplantation. Bone Marrow Transplant. 2001; 28(5):479-484. [PubMed: 11593321]

12. Nichols WG, Gooley T, Boeckh M. Community-acquired respiratory syncytial virus and parainfluenza virus infections after hematopoietic stem cell transplantation: the Fred Hutchinson Cancer Research Center experience. Biol Blood Marrow Transplant. 2001; 7(Suppl):11S-15S. [PubMed: 11777098]

13. Whimbey E, Englund JA, Couch RB. Community respiratory virus infections in immunocompromised patients with cancer. Am J Med. 1997; 102(3A):10-18. discussion 25-26. [PubMed: 10868137]

14. Ghosh S, Champlin RE, Englund J, et al. Respiratory syncytial virus upper respiratory tract illnesses in adult blood and marrow transplant recipients: combination therapy with aerosolized ribavirin and intravenous immunoglobulin. Bone Marrow Transplant. 2000; 25(7):751-755. [PubMed: 10745261]

15. Martino R, Porras RP, Rabella N, et al. Prospective study of the incidence, clinical features, and outcome of symptomatic upper and lower respiratory tract infections by respiratory viruses in adult recipients of hematopoietic stem cell transplants for hematologic malignancies. Biol Blood Marrow Transplant. 2005; 11(10):781-796. [PubMed: 16182179]

16. Shah JN, Chemaly RF. Management of RSV infections in adult recipients of hematopoietic stem cell transplantation. Blood. 2011; 117(10):2755-2763. [PubMed: 21139081]

17. Chakinala MM, Walter MJ. Community acquired respiratory viral infections after lung transplantation: clinical features and long-term consequences. Semin Thorac Cardiovasc Surg. 2004; 16(4):342-349. [PubMed: 15635538]

18. Glanville AR, Scott AI, Morton JM, et al. Intravenous ribavirin is a safe and cost-effective treatment for respiratory syncytial virus infection after lung transplantation. J Heart Lung Transplant. 2005; 24(12):2114-2119. [PubMed: 16364859]

19. Khalifah AP, Hachem RR, Chakinala MM, et al. Respiratory viral infections are a distinct risk for bronchiolitis obliterans syndrome and death. Am J Respir Crit Care Med. 2004; 170(2):181-187. [PubMed: 15130908]

20. McCurdy LH, Milstone A, Dummer S. Clinical features and outcomes of paramyxoviral infection in lung transplant recipients treated with ribavirin. J Heart Lung Transplant. 2003; 22(7):745-753. [PubMed: 12873542]

21. Milstone AP, Brumble LM, Barnes J, et al. A single-season prospective study of respiratory viral infections in lung transplant recipients. Eur Respir J. 2006; 28(1):131-137. [PubMed: 16510454]

22. Palmer SM Jr, Henshaw NG, Howell DN, Miller SE, Davis RD, Tapson VF. Community respiratory viral infection in adult lung transplant recipients. Chest. 1998; 113(4):944-950. [PubMed: 9554629] 
23. Gottlieb J, Schulz TF, Welte T, et al. Community-acquired respiratory viral infections in lung transplant recipients: a single season cohort study. Transplantation. 2009; 87(10):1530-1537. [PubMed: 19461490]

24. Miller RB, Chavers BM. Respiratory syncytial virus infections in pediatric renal transplant recipients. Pediatr Nephrol. 1996; 10(2):213-215. [PubMed: 8703717]

25. Pohl C, Green M, Wald ER, Ledesma-Medina J. Respiratory syncytial virus infections in pediatric liver transplant recipients. J Infect Dis. 1992; 165(1):166-169. [PubMed: 1727886]

26. Ison MG, Michaels MG. AST Infectious Diseases Community of Practice. RNA respiratory viral infections in solid organ transplant recipients. Am J Transplant. 2009; 9(Suppl 4):S166-S172. [PubMed: 20070677]

27. Hall CB, Douglas RG Jr. Modes of transmission of respiratory syncytial virus. J Pediatr. 1981; 99(1):100-103. [PubMed: 7252646]

28. Hall CB, Douglas RG Jr, Schnabel KC, Geiman JM. Infectivity of respiratory syncytial virus by various routes of inoculation. Infect Immun. 1981; 33(3):779-783. [PubMed: 7287181]

29. Hall CB, Douglas RG Jr, Geiman JM. Quantitative shedding patterns of respiratory syncytial virus in infants. J Infect Dis. 1975; 132(2):151-156. [PubMed: 808581]

30. Hall CB, Walsh EE, Schnabel KC, et al. Occurrence of groups A and B of respiratory syncytial virus over 15 years: associated epidemiologic and clinical characteristics in hospitalized and ambulatory children. J Infect Dis. 1990; 162(6):1283-1290. [PubMed: 2230258]

31. Jalal H, Bibby DF, Bennett J, et al. Molecular investigations of an outbreak of parainfluenza virus type 3 and respiratory syncytial virus infections in a hematology unit. J Clin Microbiol. 2007; 45(6):1690-1696. [PubMed: 17392447]

32. Taylor GS, Vipond IB, Caul EO. Molecular epidemiology of outbreak of respiratory syncytial virus within bone marrow transplantation unit. J Clin Microbiol. 2001; 39(2):801-803. [PubMed: 11158157]

33. Whimbey E, Champlin RE, Couch RB, et al. Community respiratory virus infections among hospitalized adult bone marrow transplant recipients. Clin Infect Dis. 1996; 22(5):778-782. [PubMed: 8722930]

34. Kassis C, Champlin RE, Hachem RY, et al. Detection and control of a nosocomial respiratory syncytial virus outbreak in a stem cell transplantation unit: the role of palivizumab. Biol Blood Marrow Transplant. 2010; 16(9):1265-1271. [PubMed: 20304082]

35. Machado AF, Sallum MA, Vilas Boas LS, Tateno AF, Machado CM. Molecular characterization of strains of respiratory syncytial virus identified in a hematopoietic stem cell transplant outpatient unit over 2 years: community or nosocomial infection? Biol Blood Marrow Transplant. 2008; 14(12):1348-1355. [PubMed: 19041056]

36. Avetisyan G, Mattsson J, Sparrelid E, Ljungman P. Respiratory syncytial virus infection in recipients of allogeneic stem-cell transplantation: a retrospective study of the incidence, clinical features, and outcome. Transplantation. 2009; 88(10):1222-1226. [PubMed: 19935377]

37. Hoffman SJ, Laham FR, Polack FP. Mechanisms of illness during respiratory syncytial virus infection: the lungs, the virus and the immune response. Microbes Infect. 2004; 6(8):767-772. [PubMed: 15207824]

38. Johnson JE, Gonzales RA, Olson SJ, Wright PF, Graham BS. The histopathology of fatal untreated human respiratory syncytial virus infection. Mod Pathol. 2007; 20(1):108-119. [PubMed: 17143259]

39. Everard ML, Swarbrick A, Wrightham M, et al. Analysis of cells obtained by bronchial lavage of infants with respiratory syncytial virus infection. Arch Dis Child. 1994; 71(5):428-432. [PubMed: 7826113]

40. Nadal D, Wunderli W, Meurmann O, Briner J, Hirsig J. Isolation of respiratory syncytial virus from liver tissue and extrahepatic biliary atresia material. Scand J Infect Dis. 1990; 22(1):91-93. [PubMed: 2320967]

41. Zlateva KT, Van Ranst M. Detection of subgroup B respiratory syncytial virus in the cerebrospinal fluid of a patient with respiratory syncytial virus pneumonia. Pediatr Infect Dis J. 2004; 23(11): 1065-1066. [PubMed: 15545869] 
42. Garofalo RP, Hintz KH, Hill V, Patti J, Ogra PL, Welliver RCSr. A comparison of epidemiologic and immunologic features of bronchiolitis caused by influenza virus and respiratory syncytial virus. J Med Virol. 2005; 75(2):282-289. [PubMed: 15602730]

43. Garofalo RP, Patti J, Hintz KA, Hill V, Ogra PL, Welliver RC. Macrophage inflammatory protein-1alpha (not $\mathrm{T}$ helper type 2 cytokines) is associated with severe forms of respiratory syncytial virus bronchiolitis. J Infect Dis. 2001; 184(4):393-399. [PubMed: 11471095]

44. Jamaluddin M, Choudhary S, Wang S, et al. Respiratory syncytial virus-inducible BCL-3 expression antagonizes the STAT/IRF and NF-kappaB signaling pathways by inducing histone deacetylase 1 recruitment to the interleukin-8 promoter. J Virol. 2005; 79(24):15302-15313. [PubMed: 16306601]

45. Legg JP, Hussain IR, Warner JA, Johnston SL, Warner JO. Type 1 and type 2 cytokine imbalance in acute respiratory syncytial virus bronchiolitis. Am J Respir Crit Care Med. 2003; 168(6):633639. [PubMed: 12773328]

46. Matsuda K, Tsutsumi H, Okamoto Y, Chiba C. Development of interleukin 6 and tumor necrosis factor alpha activity in nasopharyngeal secretions of infants and children during infection with respiratory syncytial virus. Clin Diagn Lab Immunol. 1995; 2(3):322-324. [PubMed: 7664179]

47. Smyth RL, Fletcher JN, Thomas HM, Hart CA. Immunological responses to respiratory syncytial virus infection in infancy. Arch Dis Child. 1997; 76(3):210-214. [PubMed: 9135260]

48. Tripp RA, Moore D, Barskey AIV, et al. Peripheral blood mononuclear cells from infants hospitalized because of respiratory syncytial virus infection express T helper-1 and T helper-2 cytokines and CC chemokine messenger RNA. J Infect Dis. 2002; 185(10):1388-1394. [PubMed: 11992272]

49. Welliver RC, Garofalo RP, Ogra PL. Beta-chemokines, but neither T helper type 1 nor T helper type 2 cytokines, correlate with severity of illness during respiratory syncytial virus infection. Pediatr Infect Dis J. 2002; 21(5):457-461. [PubMed: 12150192]

50. Khanna N, Widmer AF, Decker M, et al. Respiratory syncytial virus infection in patients with hematological diseases: single-center study and review of the literature. Clin Infect Dis. 2008; 46(3):402-412. [PubMed: 18181739]

51. Schiffer JT, Kirby K, Sandmaier B, Storb R, Corey L, Boeckh M. Timing and severity of community acquired respiratory virus infections after myeloablative versus nonmyeloablative hematopoietic stem cell transplantation. Haematologica. 2009; 94(8):1101-1108. [PubMed: 19644142]

52. Martino R, Piñana JL, Parody R, et al. Lower respiratory tract respiratory virus infections increase the risk of invasive aspergillosis after a reduced-intensity allogeneic hematopoietic SCT. Bone Marrow Transplant. 2009; 44(11):749-756. [PubMed: 19398963]

53. Hall CB, Hall WJ, Gala CL, MaGill FB, Leddy JP. Long-term prospective study in children after respiratory syncytial virus infection. J Pediatr. 1984; 105(3):358-364. [PubMed: 6470859]

54. Sigurs N, Bjarnason R, Sigurbergsson F, Kjellman B. Respiratory syncytial virus bronchiolitis in infancy is an important risk factor for asthma and allergy at age 7. Am J Respir Crit Care Med. 2000; 161(5):1501-1507. [PubMed: 10806145]

55. Sigurs N, Bjarnason R, Sigurbergsson F, Kjellman B, Björkstén B. Asthma and immunoglobulin E antibodies after respiratory syncytial virus bronchiolitis: a prospective cohort study with matched controls. Pediatrics. 1995; 95(4):500-505. [PubMed: 7700748]

56. Sigurs N, Gustafsson PM, Bjarnason R, et al. Severe respiratory syncytial virus bronchiolitis in infancy and asthma and allergy at age 13. Am J Respir Crit Care Med. 2005; 171(2):137-141. [PubMed: 15516534]

57. Stein RT, Sherrill D, Morgan WJ, et al. Respiratory syncytial virus in early life and risk of wheeze and allergy by age 13 years. Lancet. 1999; 354(9178):541-545. [PubMed: 10470697]

58. Hall WJ, Hall CB, Speers DM. Respiratory syncytial virus infection in adults: clinical, virologic, and serial pulmonary function studies. Ann Intern Med. 1978; 88(2):203-205. [PubMed: 415653]

59. Erard V, Chien JW, Kim HW, et al. Airflow decline after myeloablative allogeneic hematopoietic cell transplantation: the role of community respiratory viruses. J Infect Dis. 2006; 193(12):16191625. [PubMed: 16703503] 
60. Hopkins P, McNeil K, Kermeen F, et al. Human metapneumovirus in lung transplant recipients and comparison to respiratory syncytial virus. Am J Respir Crit Care Med. 2008; 178(8):876-881. [PubMed: 18658110]

61. Shah PD, McDyer JF. Viral infections in lung transplant recipients. Semin Respir Crit Care Med. 2010; 31(2):243-254. [PubMed: 20354936]

62. Casiano-Colón AE, Hulbert BB, Mayer TK, Walsh EE, Falsey AR. Lack of sensitivity of rapid antigen tests for the diagnosis of respiratory syncytial virus infection in adults. J Clin Virol. 2003; 28(2):169-174. [PubMed: 12957187]

63. Moore C, Valappil M, Corden S, Westmoreland D. Enhanced clinical utility of the NucliSens EasyQ RSV A + B Assay for rapid detection of respiratory syncytial virus in clinical samples. Eur J Clin Microbiol Infect Dis. 2006; 25(3):167-174. [PubMed: 16534566]

64. Palivizumab, a humanized respiratory syncytial virus monoclonal antibody, reduces hospitalization from respiratory syncytial virus infection in high-risk infants. The IMpact-RSV Study Group. Pediatrics. 1998; 102(3 Pt 1):531-537.

65. Boeckh M, Englund J, Li Y, et al. NIAID Collaborative Antiviral Study Group. Randomized controlled multicenter trial of aerosolized ribavirin for respiratory syncytial virus upper respiratory tract infection in hematopoietic cell transplant recipients. Clin Infect Dis. 2007; 44(2):245-249. [PubMed: 17173225]

66. Sparrelid E, Ljungman P, Ekelöf-Andström E, et al. Ribavirin therapy in bone marrow transplant recipients with viral respiratory tract infections. Bone Marrow Transplant. 1997; 19(9):905-908. [PubMed: 9156264]

67. Ghosh S, Champlin RE, Ueno NT, et al. Respiratory syncytial virus infections in autologous blood and marrow transplant recipients with breast cancer: combination therapy with aerosolized ribavirin and parenteral immunoglobulins. Bone Marrow Transplant. 2001; 28(3):271-275. [PubMed: 11535995]

68. Markovic SN, Adlakha A, Smith TF, Walker RC. Respiratory syncytial virus pneumonitis-induced diffuse alveolar damage in an autologous bone marrow transplant recipient. Mayo Clin Proc. 1998; 73(2):153-156. [PubMed: 9472999]

69. Small TN, Casson A, Malak SF, et al. Respiratory syncytial virus infection following hematopoietic stem cell transplantation. Bone Marrow Transplant. 2002; 29(4):321-327. [PubMed: 11896429]

70. Boeckh M, Berrey MM, Bowden RA, Crawford SW, Balsley J, Corey L. Phase 1 evaluation of the respiratory syncytial virus-specific monoclonal antibody palivizumab in recipients of hematopoietic stem cell transplants. J Infect Dis. 2001; 184(3):350-354. [PubMed: 11443562]

71. Tsitsikas DA, Oakervee H, Cavenagh JD, Gribben J, Agrawal SG, Mattes FM. Treatment of respiratory syncytial virus infection in haemopoietic stem cell transplant recipients with aerosolized ribavirin and the humanized monoclonal antibody palivizumab: a single centre experience. Br J Haematol. 2009; 146(5):574-576. [PubMed: 19538531]

72. Lambert DM, Barney S, Lambert AL, et al. Peptides from conserved regions of paramyxovirus fusion (F) proteins are potent inhibitors of viral fusion. Proc Natl Acad Sci U S A. 1996; 93(5): 2186-2191. [PubMed: 8700906]

73. Heilman CA. From the National Institute of Allergy and Infectious Diseases the World Health Organization. Respiratory syncytial and parainfluenza viruses. J Infect Dis. 1990; 161(3):402-406. [PubMed: 2155971]

74. Henderson FW. Pulmonary infections with respiratory syncytial virus and the parainfluenza viruses. Semin Respir Infect. 1987; 2(2):112-121. [PubMed: 2827280]

75. Reed G, Jewett PH, Thompson J, Tollefson S, Wright PF. Epidemiology and clinical impact of parainfluenza virus infections in otherwise healthy infants and young children $<5$ years old. $\mathrm{J}$ Infect Dis. 1997; 175(4):807-813. [PubMed: 9086134]

76. Hall CB. Respiratory syncytial virus and parainfluenza virus. N Engl J Med. 2001; 344(25):19171928. [PubMed: 11419430]

77. Tyrrell DA, Bynoe ML, Petersen KB, Sutton RN, Pereira MS. Inoculation of human volunteers with parainfluenza viruses types 1 and 3 (HA 2 and HA 1). BMJ. 1959; 2(5157):909-911.

[PubMed: 13840113] 
78. Avadhanula V, Rodriguez CA, Devincenzo JP, et al. Respiratory viruses augment the adhesion of bacterial pathogens to respiratory epithelium in a viral species- and cell type-dependent manner. $\mathrm{J}$ Virol. 2006; 80(4):1629-1636. [PubMed: 16439519]

79. Wendt CH, Weisdorf DJ, Jordan MC, Balfour HH Jr, Hertz MI. Parainfluenza virus respiratory infection after bone marrow transplantation. N Engl J Med. 1992; 326(14):921-926. [PubMed: 1311800]

80. Nichols WG, Corey L, Gooley T, Davis C, Boeckh M. Parainfluenza virus infections after hematopoietic stem cell transplantation: risk factors, response to antiviral therapy, and effect on transplant outcome. Blood. 2001; 98(3):573-578. [PubMed: 11468152]

81. Elizaga J, Olavarria E, Apperley J, Goldman J, Ward K. Parainfluenza virus 3 infection after stem cell transplant: relevance to outcome of rapid diagnosis and ribavirin treatment. Clin Infect Dis. 2001; 32(3):413-418. [PubMed: 11170949]

82. Lewis VA, Champlin R, Englund J, et al. Respiratory disease due to parainfluenza virus in adult bone marrow transplant recipients. Clin Infect Dis. 1996; 23(5):1033-1037. [PubMed: 8922798]

83. Peck AJ, Englund JA, Kuypers J, et al. Respiratory virus infection among hematopoietic cell transplant recipients: evidence for asymptomatic parainfluenza virus infection. Blood. 2007; 110(5):1681-1688. [PubMed: 17502457]

84. Hodson A, Kasliwal M, Streetly M, Macmahon E, Raj K. A parainfluenza-3 outbreak in a SCT unit: sepsis with multi-organ failure and multiple co-pathogens are associated with increased mortality. Bone Marrow Transplant. 2011 Jan.:24. [Epub ahead of print]. [PubMed: 21399670]

85. Kuypers J, Campbell AP, Cent A, Corey L, Boeckh M. Comparison of conventional and molecular detection of respiratory viruses in hematopoietic cell transplant recipients. Transpl Infect Dis. 2009; 11(4):298-303. [PubMed: 19453994]

86. Marx A, Gary HE Jr, Marston BJ, et al. Parainfluenza virus infection among adults hospitalized for lower respiratory tract infection. Clin Infect Dis. 1999; 29(1):134-140. [PubMed: 10433576]

87. Hall CB. Hospital-acquired pneumonia in children: the role of respiratory viruses. Semin Respir Infect. 1987; 2(1):48-56. [PubMed: 2827278]

88. Zambon M, Bull T, Sadler CJ, Goldman JM, Ward KN. Molecular epidemiology of two consecutive outbreaks of parainfluenza 3 in a bone marrow transplant unit. J Clin Microbiol. 1998; 36(8):2289-2293. [PubMed: 9666007]

89. Chakrabarti S, Avivi I, Mackinnon S, et al. Respiratory virus infections in transplant recipients after reduced-intensity conditioning with Campath-1H: high incidence but low mortality. Br J Haematol. 2002; 119(4):1125-1132. [PubMed: 12472597]

90. Kumar D, Husain S, Chen MH, et al. A prospective molecular surveillance study evaluating the clinical impact of community-acquired respiratory viruses in lung transplant recipients. Transplantation. 2010; 89(8):1028-1033. [PubMed: 20075787]

91. Vilchez RA, McCurry K, Dauber J, et al. The epidemiology of parainfluenza virus infection in lung transplant recipients. Clin Infect Dis. 2001; 33(12):2004-2008. [PubMed: 11702289]

92. Welliver RC, Wong DT, Middleton E Jr, Sun M, McCarthy N, Ogra PL. Role of parainfluenza virus-specific IgE in pathogenesis of croup and wheezing subsequent to infection. J Pediatr. 1982; 101(6):889-896. [PubMed: 6183418]

93. Welliver RC, Wong DT, Sun M, McCarthy N. Parainfluenza virus bronchiolitis. Epidemiology and pathogenesis. Am J Dis Child. 1986; 140(1):34-40. [PubMed: 3002169]

94. Porter DD, Prince GA, Hemming VG, Porter HG. Pathogenesis of human parainfluenza virus 3 infection in two species of cotton rats: Sigmodon hispidus develops bronchiolitis, while Sigmodon fulviventer develops interstitial pneumonia. J Virol. 1991; 65(1):103-111. [PubMed: 1845878]

95. Prince GA, Porter DD. Treatment of parainfluenza virus type 3 bronchiolitis and pneumonia in a cotton rat model using topical antibody and glucocorticosteroid. J Infect Dis. 1996; 173(3):598608. [PubMed: 8627023]

96. Ferguson PE, Sorrell TC, Bradstock KF, Carr P, Gilroy NM. Parainfluenza virus type 3 pneumonia in bone marrow transplant recipients: multiple small nodules in highresolution lung computed tomography scans provide a radiological clue to diagnosis. Clin Infect Dis. 2009 Feb.: 17. [Epub ahead of print]. 
97. Vilchez RA, Dauber J, McCurry K, Iacono A, Kusne S. Parainfluenza virus infection in adult lung transplant recipients: an emergent clinical syndrome with implications on allograft function. Am J Transplant. 2003; 3(2):116-120. [PubMed: 12603206]

98. Holt ND, Gould FK, Taylor CE, et al. Incidence and significance of noncytomegalovirus viral respiratory infection after adult lung transplantation. J Heart Lung Transplant. 1997; 16(4):416419. [PubMed: 9154952]

99. Wendt CH, Fox JM, Hertz MI. Paramyxovirus infection in lung transplant recipients. J Heart Lung Transplant. 1995; 14(3):479-485. [PubMed: 7654733]

100. DeFabritus AM, Riggio RR, David DS, Senterfit LB, Cheigh JS, Stenzel KH. Parainfluenza type 3 in a transplant unit. JAMA. 1979; 241(4):384-386. [PubMed: 214588]

101. Herzog KD, Dunn SP, Langham MR Jr, Marmon LM. Association of parainfluenza virus type 3 infection with allograft rejection in a liver transplant recipient. Pediatr Infect Dis J. 1989; 8(8): 534-536. [PubMed: 2549495]

102. Laurichesse H, Dedman D, Watson JM, Zambon MC. Epidemiological features of parainfluenza virus infections: laboratory surveillance in England and Wales, 1975-1997. Eur J Epidemiol. 1999; 15(5):475-484. [PubMed: 10442474]

103. Brady MT, Evans J, Cuartas J. Survival and disinfection of parainfluenza viruses on environmental surfaces. Am J Infect Control. 1990; 18(1):18-23. [PubMed: 2156469]

104. Henrickson KJ. Parainfluenza viruses. Clin Microbiol Rev. 2003; 16(2):242-264. [PubMed: 12692097]

105. Stankova J, Carret AS, Moore D, et al. Long-term therapy with aerosolized ribavirin for parainfluenza 3 virus respiratory tract infection in an infant with severe combined immunodeficiency. Pediatr Transplant. 2007; 11(2):209-213. [PubMed: 17300503]

106. Murrell M, Porotto M, Weber T, Greengard O, Moscona A. Mutations in human parainfluenza virus type 3 hemagglutinin-neuraminidase causing increased receptor binding activity and resistance to the transition state sialic acid analog 4-GU-DANA (Zanamivir). J Virol. 2003; 77(1):309-317. [PubMed: 12477836]

107. Alymova IV, Taylor G, Takimoto T, et al. Efficacy of novel hemagglutinin-neuraminidase inhibitors BCX 2798 and BCX 2855 against human parainfluenza viruses in vitro and in vivo. Antimicrob Agents Chemother. 2004; 48(5):1495-1502. [PubMed: 15105096]

108. Watanabe M, Mishin VP, Brown SA, et al. Effect of hemagglutinin-neuraminidase inhibitors BCX 2798 and BCX 2855 on growth and pathogenicity of Sendai/human parainfluenza type 3 chimera virus in mice. Antimicrob Agents Chemother. 2009; 53(9):3942-3951. [PubMed: 19564364]

109. Ljungman P. Respiratory virus infections in bone marrow transplant recipients: the European perspective. Am J Med. 1997; 102(3A):44-47. [PubMed: 10868142]

110. Bowden RA. Respiratory virus infections after marrow transplant: the Fred Hutchinson Cancer Research Center experience. Am J Med. 1997; 102(3A):27-30. discussion 42-43. [PubMed: 10868139]

111. Nichols WG, Guthrie KA, Corey L, Boeckh M. Influenza infections after hematopoietic stem cell transplantation: risk factors, mortality, and the effect of antiviral therapy. Clin Infect Dis. 2004; 39(9):1300-1306. [PubMed: 15494906]

112. Vilchez R, McCurry K, Dauber J, et al. Influenza and parainfluenza respiratory viral infection requiring admission in adult lung transplant recipients. Transplantation. 2002; 73(7):1075-1078. [PubMed: 11965034]

113. López-Medrano F, Aguado JM, Lizasoain M, et al. Clinical implications of respiratory virus infections in solid organ transplant recipients: a prospective study. Transplantation. 2007; 84(7): 851-856. [PubMed: 17984837]

114. Vilchez RA, McCurry K, Dauber J, et al. Influenza virus infection in adult solid organ transplant recipients. Am J Transplant. 2002; 2(3):287-291. [PubMed: 12096793]

115. Maurer JR, Tullis DE, Grossman RF, Vellend H, Winton TL, Patterson GA. Infectious complications following isolated lung transplantation. Chest. 1992; 101(4):1056-1059. [PubMed: 1555420] 
116. Kramer MR, Marshall SE, Starnes VA, Gamberg P, Amitai Z, Theodore J. Infectious complications in heart-lung transplantation. Analysis of 200 episodes. Arch Intern Med. 1993; 153(17):2010-2016. [PubMed: 8357286]

117. Ohori NP, Michaels MG, Jaffe R, Williams P, Yousem SA. Adenovirus pneumonia in lung transplant recipients. Hum Pathol. 1995; 26(10):1073-1079. [PubMed: 7557939]

118. Billings JL, Hertz MI, Savik K, Wendt CH. Respiratory viruses and chronic rejection in lung transplant recipients. J Heart Lung Transplant. 2002; 21(5):559-566. [PubMed: 11983546]

119. Weinberg A, Lyu DM, Li S, Marquesen J, Zamora MR. Incidence and morbidity of human metapneumovirus and other community-acquired respiratory viruses in lung transplant recipients. Transpl Infect Dis. 2010; 12(4):330-335. [PubMed: 20456714]

120. Fox BD, Raviv Y, Rozengarten D, Rusanov V, Bakal I, Kramer MR. Pandemic influenza (H1N1): impact on lung transplant recipients and candidates. J Heart Lung Transplant. 2010; 29(9):1034-1038. [PubMed: 20558087]

121. Choi SM, Boudreault AA, Xie H, Englund JA, Corey L, Boeckh M. Differences in clinical outcomes following 2009 influenza A/H1N1 and seasonal influenza among hematopoietic cell transplant recipients. Blood. 2011; 117(19):5050-5056. [PubMed: 21372154]

122. Whimbey E, Elting LS, Couch RB, et al. Influenza A virus infections among hospitalized adult bone marrow transplant recipients. Bone Marrow Transplant. 1994; 13(4):437-440. [PubMed: 8019468]

123. Malavaud S, Malavaud B, Sandres K, et al. Nosocomial outbreak of influenza virus A (H3N2) infection in a solid organ transplant department. Transplantation. 2001; 72(3):535-537. [PubMed: 11502991]

124. Garbino J, Gerbase MW, Wunderli W, et al. Respiratory viruses and severe lower respiratory tract complications in hospitalized patients. Chest. 2004; 125(3):1033-1039. [PubMed: 15006965]

125. Meylan PR, Aubert JD, Kaiser L. Influenza transmission to recipient through lung transplantation. Transpl Infect Dis. 2007; 9(1):55-57. [PubMed: 17313474]

126. Le Page AK, Kainer G, Glanville AR, Tu E, Bhonagiri D, Rawlinson WD. Influenza B virus transmission in recipients of kidney and lung transplants from an infected donor. Transplantation. 2010; 90(1):99-102. [PubMed: 20606569]

127. International Society of Heart and Lung Transplantation. [Accessed May 15, 2009] tAdvisory statement on the implications of pandemic influenza for thoracic organ transplantation. 2009. http://www.ishlt.org/ContentDocuments/ISHLTInfluenzaPandemicRapidAdvisory.pdf.

128. OPTN/UNOS guidance regarding H1N1 and implications for transplantation. [Accessed January 7, 2010] http://optn.transplant.hrsa.gov/news/newsDetail.asp?id=1292.

129. Lee SH, Cheuh H, Yoo KH, et al. Hematopoietic stem cell transplantation from a related donor infected with influenza H1N1 2009. Transpl Infect Dis. 2011 Feb.:23. [Epub ahead of print].

130. Smith GJ, Vijaykrishna D, Bahl J, et al. Origins and evolutionary genomics of the 2009 swineorigin H1N1 influenza A epidemic. Nature. 2009; 459(7250):1122-1125. [PubMed: 19516283]

131. Garten RJ, Davis CT, Russell CA, et al. Antigenic and genetic characteristics of swine-origin 2009 A(H1N1) influenza viruses circulating in humans. Science. 2009; 325(5937):197-201. [PubMed: 19465683]

132. Dawood FS, Jain S, Finelli L, et al. Novel Swine-Origin Influenza A (H1N1) Virus Investigation Team. Emergence of a novel swine-origin influenza A (H1N1) virus in humans. N Engl J Med. 2009; 360(25):2605-2615. [PubMed: 19423869]

133. van der Sluijs KF, van Elden LJ, Nijhuis M, et al. IL-10 is an important mediator of the enhanced susceptibility to pneumococcal pneumonia after influenza infection. J Immunol. 2004; 172(12): 7603-7609. [PubMed: 15187140]

134. Sun K, Metzger DW. Inhibition of pulmonary antibacterial defense by interferon-gamma during recovery from influenza infection. Nat Med. 2008; 14(5):558-564. [PubMed: 18438414]

135. Keane WR, Helderman JH, Luby J, Gailiunas P, Hull AR, Kokko JP. Epidemic renal transplant rejection associated with influenza A victoria. Proc Clin Dial Transplant Forum. 1978; 8:232236. [PubMed: 386316]

136. Aschan J, Ringdén O, Ljungman P, Andersson J, Lewensohn-Fuchs I, Forsgren M. Influenza B in transplant patients. Scand J Infect Dis. 1989; 21(3):349-350. [PubMed: 2667101] 
137. Ljungman P, Andersson J, Aschan J, et al. Influenza A in immunocompromised patients. Clin Infect Dis. 1993; 17(2):244-247. [PubMed: 8399875]

138. Mauch TJ, Bratton S, Myers T, Krane E, Gentry SR, Kashtan CE. Influenza B virus infection in pediatric solid organ transplant recipients. Pediatrics. 1994; 94(2 Pt 1):225-229. [PubMed: 8036078]

139. Khanna N, Steffen I, Studt JD, et al. Outcome of influenza infections in outpatients after allogeneic hematopoietic stem cell transplantation. Transpl Infect Dis. 2009; 11(2):100-105. [PubMed: 19175540]

140. Apalsch AM, Green M, Ledesma-Medina J, Nour B, Wald ER. Parainfluenza and influenza virus infections in pediatric organ transplant recipients. Clin Infect Dis. 1995; 20(2):394-399. [PubMed: 7742447]

141. La Rosa, AM.; Malik, S.; Englund, JA., et al. Influenza A in hospitalized adults with leukemia and hematopoietic stem cell transplant (HSCT) recipients; risk factors for progression to pneumonia; San Francisco, CA. Paper presented at: 39th Annual Meeting of the Infectious Diseases Society of America; 2001 Oct. p. 25-28.

142. Protheroe RE, Kirkland KE, Pearce RM, et al. The clinical features and outcome of 2009 H1N1 influenza infection in Allo-SCT patients: a British Society of Blood and Marrow Transplantation study. Bone Marrow Transplant. 2011 Feb.:28. [Epub ahead of print].

143. Girmenia C, Mercanti C, Federico V, et al. Management of the 2009 A/H1N1 influenza pandemic in patients with hematologic diseases: a prospective experience at an Italian center. Acta Haematol. 2011; 126(1):1-7. [PubMed: 21411983]

144. Rihani R, Hayajneh W, Sultan I, et al. Infections with the 2009 H1N1 influenza virus among hematopoietic SCT recipients: a single center experience. Bone Marrow Transplant. 2011 Jan.: 17. [Epub ahead of print]. [PubMed: 21042308]

145. Espinosa-Aguilar L, Green JS, Forrest GN, et al. Novel H1N1 influenza in hematopoietic stem cell transplantation recipients: two centers' experiences. Biol Blood Marrow Transplant. 2011; 17(4):566-573. [PubMed: 20708084]

146. Low CY, Kee T, Chan KP, et al. Pandemic (H1N1) 2009 infection in adult solid organ transplant recipients in Singapore. Transplantation. 2010; 90(9):1016-1021. [PubMed: 20814355]

147. Kumar D, Erdman D, Keshavjee S, et al. Clinical impact of community-acquired respiratory viruses on bronchiolitis obliterans after lung transplant. Am J Transplant. 2005; 5(8):2031-2036. [PubMed: 15996256]

148. Faul JL, Akindipe OA, Berry GJ, Theodore J. Influenza pneumonia in a paediatric lung transplant recipient. Transpl Int. 2000; 13(1):79-81. [PubMed: 10743695]

149. Garantziotis S, Howell DN, McAdams HP, Davis RD, Henshaw NG, Palmer SM. Influenza pneumonia in lung transplant recipients: clinical features and association with bronchiolitis obliterans syndrome. Chest. 2001; 119(4):1277-1280. [PubMed: 11296201]

150. Petric M, Comanor L, Petti CA. Role of the laboratory in diagnosis of influenza during seasonal epidemics and potential pandemics. J Infect Dis. 2006; 194(Suppl 2):S98-S110. [PubMed: 17163396]

151. Weinberg A, Zamora MR, Li S, Torres F, Hodges TN. The value of polymerase chain reaction for the diagnosis of viral respiratory tract infections in lung transplant recipients. J Clin Virol. 2002; 25(2):171-175. [PubMed: 12367651]

152. van Kraaij MG, van Elden LJ, van Loon AM, et al. Frequent detection of respiratory viruses in adult recipients of stem cell transplants with the use of real-time polymerase chain reaction, compared with viral culture. Clin Infect Dis. 2005; 40(5):662-669. [PubMed: 15714410]

153. Danzinger-Isakov L, Kumar D. AST Infectious Diseases Community of Practice. Guidelines for vaccination of solid organ transplant candidates and recipients. Am J Transplant. 2009; 9(Suppl 4):S258-S262. [PubMed: 20070687]

154. Ljungman P, Avetisyan G. Influenza vaccination in hematopoietic SCT recipients. Bone Marrow Transplant. 2008; 42(10):637-641. [PubMed: 18724396]

155. Hayney MS, Moran J, Wiegert NA, Burlingham WJ. Lung transplant patients' T cell responses to influenza vaccine viruses between seasons. Vaccine. 2008; 26(21):2596-2600. [PubMed: 18420314] 
156. Mazzone PJ, Mossad SB, Mawhorter SD, Mehta AC, Schilz RJ, Maurer JR. The humoral immune response to influenza vaccination in lung transplant patients. Eur Respir J. 2001; 18(6):971-976. [PubMed: 11829104]

157. Fiore AE, Fry A, Shay D, Gubareva L, Bresee JS, Uyeki TM. Centers for Disease Control and Prevention (CDC). Antiviral agents for the treatment and chemoprophylaxis of influenzarecommendations of the Advisory Committee on Immunization Practices (ACIP). MMWR Recomm Rep. 2011; 60(1):1-24. [PubMed: 21248682]

158. Johny AA, Clark A, Price N, Carrington D, Oakhill A, Marks DI. The use of zanamivir to treat influenza A and B infection after allogeneic stem cell transplantation. Bone Marrow Transplant. 2002; 29(2):113-115. [PubMed: 11850704]

159. Ison MG, Sharma A, Shepard JA, Wain JC, Ginns LC. Outcome of influenza infection managed with oseltamivir in lung transplant recipients. J Heart Lung Transplant. 2008; 27(3):282-288. [PubMed: 18342750]

160. Kumar D, Morris MI, Kotton CN, et al. AST Infectious Diseases Community of Practice and Transplant Infectious Diseases Section of TTS. Guidance on novel influenza A/ H1N1 in solid organ transplant recipients. Am J Transplant. 2010; 10(1):18-25. [PubMed: 19958321]

161. Ison MG, Green M. AST Infectious Diseases Community of Practice. Adenovirus in solid organ transplant recipients. Am J Transplant. 2009; 9(Suppl 4):S161-S165. [PubMed: 20070676]

162. Barker JH, Luby JP, Sean Dalley A, Bartek WM, Burns DK, Erdman DD. Fatal type 3 adenoviral pneumonia in immunocompetent adult identical twins. Clin Infect Dis. 2003; 37(10):e142-e146. [PubMed: 14583886]

163. Dudding BA, Wagner SC, Zeller JA, Gmelich JT, French GR, Top FH Jr. Fatal pneumonia associated with adenovirus type 7 in three military trainees. N Engl J Med. 1972; 286(24):12891292. [PubMed: 4337012]

164. Filho EP, da Costa Faria NR, Fialho AM, et al. Adenoviruses associated with acute gastroenteritis in hospitalized and community children up to 5 years old in Rio de Janeiro and Salvador, Brazil. J Med Microbiol. 2007; 56(Pt 3):313-319. [PubMed: 17314359]

165. Madisch I, Wölfel R, Harste G, Pommer H, Heim A. Molecular identification of adenovirus sequences: a rapid scheme for early typing of human adenoviruses in diagnostic samples of immunocompetent and immunodeficient patients. J Med Virol. 2006; 78(9):1210-1217. [PubMed: 16847954]

166. Hársi CM, Rolim DP, Gomes SA, et al. Adenovirus genome types isolated from stools of children with gastroenteritis in Sa o Paulo, Brazil. J Med Virol. 1995; 45(2):127-134. [PubMed: 7775929]

167. Fukuda S, Kuwayama M, Takao S, Shimazu Y, Miyazaki K. Molecular epidemiology of subgenus $\mathrm{F}$ adenoviruses associated with pediatric gastroenteritis during eight years in Hiroshima Prefecture as a limited area. Arch Virol. 2006; 151(12):2511-2517. [PubMed: 16847553]

168. Sdiri-Loulizi K, Gharbi-Khelifi H, de Rougemont A, et al. Molecular epidemiology of human astrovirus and adenovirus serotypes 40/41 strains related to acute diarrhea in Tunisian children. J Med Virol. 2009; 81(11):1895-1902. [PubMed: 19774695]

169. Magwalivha M, Wolfaardt M, Kiulia NM, van Zyl WB, Mwenda JM, Taylor MB. High prevalence of species D human adenoviruses in fecal specimens from urban Kenyan children with diarrhea. J Med Virol. 2010; 82(1):77-84. [PubMed: 19950234]

170. Gonçalves G, Gouveia E, Mesquita JR, et al. Outbreak of acute gastroenteritis caused by adenovirus type 41 in a kindergarten. Epidemiol Infect. 2010 Dec.15:1-4. [Epub ahead of print].

171. Li L, Shimizu H, Doan LT, et al. Characterizations of adenovirus type 41 isolates from children with acute gastroenteritis in Japan, Vietnam, and Korea. J Clin Microbiol. 2004; 42(9):40324039. [PubMed: 15364986]

172. Marie-Cardine A, Gourlain K, Mouterde O, et al. Epidemiology of acute viral gastroenteritis in children hospitalized in Rouen, France. Clin Infect Dis. 2002; 34(9):1170-1178. [PubMed: 11941542]

173. Soares CC, Volota o EM, Albuquerque MC, et al. Prevalence of enteric adenoviruses among children with diarrhea in four Brazilian cities. J Clin Virol. 2002; 23(3):171-177. [PubMed: 11595596] 
174. Cunliffe NA, Booth JA, Elliot C, et al. Healthcare-associated viral gastroenteritis among children in a large pediatric hospital, United Kingdom. Emerg Infect Dis. 2010; 16(1):55-62. [PubMed: 20031043]

175. Iturriza, Gómara M.; Simpson, R.; Perault, AM., et al. Structured surveillance of infantile gastroenteritis in East Anglia, UK: incidence of infection with common viral gastroenteric pathogens. Epidemiol Infect. 2008; 136(1):23-33. [PubMed: 17313697]

176. Zheng X, Lu X, Erdman DD, et al. Identification of adenoviruses in specimens from high-risk pediatric stem cell transplant recipients and controls. J Clin Microbiol. 2008; 46(1):317-320. [PubMed: 17989198]

177. Ison MG. Adenovirus infections in transplant recipients. Clin Infect Dis. 2006; 43(3):331-339. [PubMed: 16804849]

178. Buffington J, Chapman LE, Stobierski MG, et al. Epidemic keratoconjunctivitis in a chronic care facility: risk factors and measures for control. J Am Geriatr Soc. 1993; 41(11):1177-1181. [PubMed: 8227890]

179. Singh-Naz N, Brown M, Ganeshananthan M. Nosocomial adenovirus infection: molecular epidemiology of an outbreak. Pediatr Infect Dis J. 1993; 12(11):922-925. [PubMed: 8265282]

180. Koneru B, Atchison R, Jaffe R, Cassavilla A, Van Thiel DH, Starzl TE. Serological studies of adenoviral hepatitis following pediatric liver transplantation. Transplant Proc. 1990; 22(4):15471548. [PubMed: 2167527]

181. Kojaoghlanian T, Flomenberg P, Horwitz MS. The impact of adenovirus infection on the immunocompromised host. Rev Med Virol. 2003; 13(3):155-171. [PubMed: 12740831]

182. Garnett CT, Erdman D, Xu W, Gooding LR. Prevalence and quantitation of species C adenovirus DNA in human mucosal lymphocytes. J Virol. 2002; 76(21):10608-10616. [PubMed: 12368303]

183. Bil-Lula I, Ussowicz M, Rybka B, et al. Hematuria due to adenoviral infection in bone marrow transplant recipients. Transplant Proc. 2010; 42(9):3729-3734. [PubMed: 21094847]

184. Echavarría M. Adenoviruses in immunocompromised hosts. Clin Microbiol Rev. 2008; 21(4): 704-715. [PubMed: 18854488]

185. Walls T, Shankar AG, Shingadia D. Adenovirus: an increasingly important pathogen in paediatric bone marrow transplant patients. Lancet Infect Dis. 2003; 3(2):79-86. [PubMed: 12560192]

186. La Rosa AM, Champlin RE, Mirza N, et al. Adenovirus infections in adult recipients of blood and marrow transplants. Clin Infect Dis. 2001; 32(6):871-876. [PubMed: 11247710]

187. Muller WJ, Levin MJ, Shin YK, et al. Clinical and in vitro evaluation of cidofovir for treatment of adenovirus infection in pediatric hematopoietic stem cell transplant recipients. Clin Infect Dis. 2005; 41(12):1812-1816. [PubMed: 16288409]

188. Bordigoni P, Carret AS, Venard V, Witz F, Le Faou A. Treatment of adenovirus infections in patients undergoing allogeneic hematopoietic stem cell transplantation. Clin Infect Dis. 2001; 32(9):1290-1297. [PubMed: 11303263]

189. de Mezerville MH, Tellier R, Richardson S, He'bert D, Doyle J, Allen U. Adenoviral infections in pediatric transplant recipients: a hospital-based study. Pediatr Infect Dis J. 2006; 25(9):815818. [PubMed: 16940840]

190. Sivaprakasam P, Carr TF, Coussons M, et al. Improved outcome from invasive adenovirus infection in pediatric patients after hemopoietic stem cell transplantation using intensive clinical surveillance and early intervention. J Pediatr Hematol Oncol. 2007; 29(2):81-85. [PubMed: 17279003]

191. Neofytos D, Ojha A, Mookerjee B, et al. Treatment of adenovirus disease in stem cell transplant recipients with cidofovir. Biol Blood Marrow Transplant. 2007; 13(1):74-81. [PubMed: 17222755]

192. Robin M, Marque-Juillet S, Scieux C, et al. Disseminated adenovirus infections after allogeneic hematopoietic stem cell transplantation: incidence, risk factors and outcome. Haematologica. 2007; 92(9):1254-1257. [PubMed: 17666361]

193. Symeonidis N, Jakubowski A, Pierre-Louis S, et al. Invasive adenoviral infections in T-celldepleted allogeneic hematopoietic stem cell transplantation: high mortality in the era of cidofovir. Transpl Infect Dis. 2007; 9(2):108-113. [PubMed: 17461995] 
194. Michaels MG, Green M, Wald ER, Starzl TE. Adenovirus infection in pediatric liver transplant recipients. J Infect Dis. 1992; 165(1):170-174. [PubMed: 1727887]

195. Humar A, Kumar D, Mazzulli T, et al. PV16000 Study Group. A surveillance study of adenovirus infection in adult solid organ transplant recipients. Am J Transplant. 2005; 5(10):2555-2559. [PubMed: 16162207]

196. McGrath D, Falagas ME, Freeman R, et al. Adenovirus infection in adult orthotopic liver transplant recipients: incidence and clinical significance. J Infect Dis. 1998; 177(2):459-462. [PubMed: 9466537]

197. Shirali GS, Ni J, Chinnock RE, et al. Association of viral genome with graft loss in children after cardiac transplantation. N Engl J Med. 2001; 344(20):1498-1503. [PubMed: 11357152]

198. Yagisawa T, Nakada T, Takahashi K, Toma H, Ota K, Yaguchi H. Acute hemorrhagic cystitis caused by adenovirus after kidney transplantation. Urol Int. 1995; 54(3):142-146. [PubMed: 7604455]

199. Yagisawa T, Takahashi K, Yamaguchi Y, et al. Adenovirus induced nephropathy in kidney transplant recipients. Transplant Proc. 1989; 21(1 Pt 2):2097-2099. [PubMed: 2540563]

200. Humar A, Doucette K, Kumar D, et al. Assessment of adenovirus infection in adult lung transplant recipients using molecular surveillance. J Heart Lung Transplant. 2006; 25(12):14411446. [PubMed: 17178339]

201. Bridges ND, Spray TL, Collins MH, Bowles NE, Towbin JA. Adenovirus infection in the lung results in graft failure after lung transplantation. J Thorac Cardiovasc Surg. 1998; 116(4):617623. [PubMed: 9766590]

202. Simsir A, Greenebaum E, Nuovo G, Schulman LL. Late fatal adenovirus pneumonitis in a lung transplant recipient. Transplantation. 1998; 65(4):592-594. [PubMed: 9500642]

203. Lee J, Choi EH, Lee HJ. Comprehensive serotyping and epidemiology of human adenovirus isolated from the respiratory tract of Korean children over 17 consecutive years (1991-2007). J Med Virol. 2010; 82(4):624-631. [PubMed: 20166176]

204. Jones MSII, Harrach B, Ganac RD, et al. New adenovirus species found in a patient presenting with gastroenteritis. J Virol. 2007; 81(11):5978-5984. [PubMed: 17360747]

205. Kajon AE, Lu X, Erdman DD, et al. Molecular epidemiology and brief history of emerging adenovirus 14-associated respiratory disease in the United States. J Infect Dis. 2010; 202(1):93103. [PubMed: 20500088]

206. Lu X, Erdman DD. Molecular typing of human adenoviruses by PCR and sequencing of a partial region of the hexon gene. Arch Virol. 2006; 151(8):1587-1602. [PubMed: 16502282]

207. Houng HS, Gong H, Kajon AE, et al. Genome sequences of human adenovirus 14 isolates from mild respiratory cases and a fatal pneumonia, isolated during 2006-2007 epidemics in North America. Respir Res. 2010; 11:116. [PubMed: 20738863]

208. Ebner K, Rauch M, Preuner S, Lion T. Typing of human adenoviruses in specimens from immunosuppressed patients by PCR-fragment length analysis and real-time quantitative PCR. J Clin Microbiol. 2006; 44(8):2808-2815. [PubMed: 16891496]

209. Walls T, Hawrami K, Ushiro-Lumb I, Shingadia D, Saha V, Shankar AG. Adenovirus infection after pediatric bone marrow transplantation: is treatment always necessary? Clin Infect Dis. 2005; 40(9):1244-1249. [PubMed: 15825025]

210. Kajon AE, Dickson LM, Metzgar D, Houng HS, Lee V, Tan BH. Outbreak of febrile respiratory illness associated with adenovirus 11a infection in a Singapore military training cAMP. J Clin Microbiol. 2010; 48(4):1438-1441. [PubMed: 20129957]

211. Chakrabarti S, Mautner V, Osman H, et al. Adenovirus infections following allogeneic stem cell transplantation: incidence and outcome in relation to graft manipulation, immunosuppression, and immune recovery. Blood. 2002; 100(5):1619-1627. [PubMed: 12176880]

212. Heemskerk B, Lankester AC, van Vreeswijk T, et al. Immune reconstitution and clearance of human adenovirus viremia in pediatric stem-cell recipients. J Infect Dis. 2005; 191(4):520-530. [PubMed: 15655775]

213. van Tol MJ, Claas EC, Heemskerk B, et al. Adenovirus infection in children after allogeneic stem cell transplantation: diagnosis, treatment and immunity. Bone Marrow Transplant. 2005; 35(Suppl 1):S73-S76. [PubMed: 15812536] 
214. Suparno C, Milligan DW, Moss PA, Mautner V. Adenovirus infections in stem cell transplant recipients: recent developments in understanding of pathogenesis, diagnosis and management. Leuk Lymphoma. 2004; 45(5):873-885. [PubMed: 15291344]

215. Ahluwalia GS, Scott-Taylor TH, Klisko B, Hammond GW. Comparison of detection methods for adenovirus from enteric clinical specimens. Diagn Microbiol Infect Dis. 1994; 18(3):161-166. [PubMed: 7924208]

216. Erard V, Huang ML, Ferrenberg J, et al. Quantitative realtime polymerase chain reaction for detection of adenovirus after T cell-replete hematopoietic cell transplantation: viral load as a marker for invasive disease. Clin Infect Dis. 2007; 45(8):958-965. [PubMed: 17879908]

217. Lankester AC, Heemskerk B, Claas EC, et al. Effect of ribavirin on the plasma viral DNA load in patients with disseminating adenovirus infection. Clin Infect Dis. 2004; 38(11):1521-1525. [PubMed: 15156436]

218. Yusuf U, Hale GA, Carr J, et al. Cidofovir for the treatment of adenoviral infection in pediatric hematopoietic stem cell transplant patients. Transplantation. 2006; 81(10):1398-1404. [PubMed: 16732176]

219. Leruez-Ville M, Minard V, Lacaille F, et al. Real-time blood plasma polymerase chain reaction for management of disseminated adenovirus infection. Clin Infect Dis. 2004; 38(1):45-52. [PubMed: 14679447]

220. Sujeet K, Vasudev B, Desai P, et al. Acute kidney injury requiring dialysis secondary to adenovirus nephritis in renal transplant recipient. Transpl Infect Dis. 2011; 13(2):174-177. [PubMed: 20946204]

221. Jernigan JA, Lowry BS, Hayden FG, et al. Adenovirus type 8 epidemic keratoconjunctivitis in an eye clinic: risk factors and control. J Infect Dis. 1993; 167(6):1307-1313. [PubMed: 8501319]

222. Finn A, Anday E, Talbot GH. An epidemic of adenovirus 7a infection in a neonatal nursery: course, morbidity, and management. Infect Control Hosp Epidemiol. 1988; 9(9):398-404. [PubMed: 2844886]

223. Morfin F, Dupuis-Girod S, Mundweiler S, et al. In vitro susceptibility of adenovirus to antiviral drugs is species-dependent. Antivir Ther. 2005; 10(2):225-229. [PubMed: 15865216]

224. Rose KM, Leonard TB, Carter TH. Effects of adenine nucleosides on RNA synthesis in adenovirus-infected cells. 9-beta-D-Arabinofuranosyladenine as a selective inhibitor of RNA polyadenylation. Mol Pharmacol. 1982; 22(2):517-523. [PubMed: 6183573]

225. Taylor DD, Jeffries DJ, Taylor-Robinson D, Parkin JM, Tyms AS. The susceptibility of adenovirus infection to the anti-cytomegalovirus drug, ganciclovir (DHPG). FEMS Microbiol Lett. 1988; 49:337-341.

226. Ljungman P. Treatment of adenovirus infections in the immunocompromised host. Eur J Clin Microbiol Infect Dis. 2004; 23(8):583-588. [PubMed: 15248091]

227. Naesens L, Lenaerts L, Andrei G, et al. Antiadenovirus activities of several classes of nucleoside and nucleotide analogues. Antimicrob Agents Chemother. 2005; 49(3):1010-1016. [PubMed: 15728896]

228. Gavin PJ, Katz BZ. Intravenous ribavirin treatment for severe adenovirus disease in immunocompromised children. Pediatrics. 2002; 110(1 Pt 1):e9. [PubMed: 12093990]

229. Hoffman JA, Shah AJ, Ross LA, Kapoor N. Adenoviral infections and a prospective trial of cidofovir in pediatric hematopoietic stem cell transplantation. Biol Blood Marrow Transplant. 2001; 7(7):388-394. [PubMed: 11529489]

230. Ljungman P, Ribaud P, Eyrich M, et al. Infectious Diseases Working Party of the European Group for Blood and Marrow Transplantation. Cidofovir for adenovirus infections after allogeneic hematopoietic stem cell transplantation: a survey by the Infectious Diseases Working Party of the European Group for Blood and Marrow Transplantation. Bone Marrow Transplant. 2003; 31(6):481-486. [PubMed: 12665844]

231. Nagafuji K, Aoki K, Henzan H, et al. Cidofovir for treating adenoviral hemorrhagic cystitis in hematopoietic stem cell transplant recipients. Bone Marrow Transplant. 2004; 34(10):909-914. [PubMed: 15361907] 
232. Fanourgiakis P, Georgala A, Vekemans M, et al. Intravesical instillation of cidofovir in the treatment of hemorrhagic cystitis caused by adenovirus type 11 in a bone marrow transplant recipient. Clin Infect Dis. 2005; 40(1):199-201. [PubMed: 15614713]

233. Keswani M, Moudgil A. Adenovirus-associated hemorrhagic cystitis in a pediatric renal transplant recipient. Pediatr Transplant. 2007; 11(5):568-571. [PubMed: 17631031]

234. Doan ML, Mallory GB, Kaplan SL, et al. Treatment of adenovirus pneumonia with cidofovir in pediatric lung transplant recipients. J Heart Lung Transplant. 2007; 26(9):883-889. [PubMed: 17845926]

235. Feuchtinger T, Matthes-Martin S, Richard C, et al. Safe adoptive transfer of virus-specific T-cell immunity for the treatment of systemic adenovirus infection after allogeneic stem cell transplantation. Br J Haematol. 2006; 134(1):64-76. [PubMed: 16803570]

236. Leen AM, Myers GD, Sili U, et al. Monoculture-derived T lymphocytes specific for multiple viruses expand and produce clinically relevant effects in immunocompromised individuals. Nat Med. 2006; 12(10):1160-1166. [PubMed: 16998485]

237. van den Hoogen BG, de Jong JC, Groen J, et al. A newly discovered human pneumovirus isolated from young children with respiratory tract disease. Nat Med. 2001; 7(6):719-724. [PubMed: 11385510]

238. Kahn JS. Epidemiology of human metapneumovirus. Clin Microbiol Rev. 2006; 19(3):546-557. [PubMed: 16847085]

239. Oliveira R, Machado A, Tateno A, Boas LV, Pannuti C, Machado C. Frequency of human metapneumovirus infection in hematopoietic SCT recipients during 3 consecutive years. Bone Marrow Transplant. 2008; 42(4):265-269. [PubMed: 18516078]

240. Greensill J, McNamara PS, Dove W, Flanagan B, Smyth RL, Hart CA. Human metapneumovirus in severe respiratory syncytial virus bronchiolitis. Emerg Infect Dis. 2003; 9(3):372-375. [PubMed: 12643835]

241. Kamboj M, Gerbin M, Huang C-K, et al. Clinical characterization of human metapneumovirus infection among patients with cancer. J Infect. 2008; 57(6):464-471. [PubMed: 19027169]

242. Garbino J, Soccal PM, Aubert JD, et al. Respiratory viruses in bronchoalveolar lavage: a hospitalbased cohort study in adults. Thorax. 2009; 64(5):399-404. [PubMed: 19174425]

243. Sumino KC, Agapov E, Pierce RA, et al. Detection of severe human metapneumovirus infection by real-time polymerase chain reaction and histopathological assessment. J Infect Dis. 2005; 192(6):1052-1060. [PubMed: 16107959]

244. Larcher C, Geltner C, Fischer H, Nachbaur D, Mu"ller LC, Huemer HP. Human metapneumovirus infection in lung transplant recipients: clinical presentation and epidemiology. J Heart Lung Transplant. 2005; 24(11):1891-1901. [PubMed: 16297797]

245. Gerna G, Vitulo P, Rovida F, et al. Impact of human metapneumovirus and human cytomegalovirus versus other respiratory viruses on the lower respiratory tract infections of lung transplant recipients. J Med Virol. 2006; 78(3):408-416. [PubMed: 16419110]

246. Debur MC, Vidal LR, Stroparo E, et al. Human metapneumovirus infection in hematopoietic stem cell transplant recipients. Transpl Infect Dis. 2010; 12(2):173-179. [PubMed: 19878491]

247. Schildgen O, Glatzel T, Geikowski T, et al. Human metapneumovirus RNA in encephalitis patient. Emerg Infect Dis. 2005; 11(3):467-470. [PubMed: 15757568]

248. Campbell AP, Chien JW, Kuypers J, et al. Respiratory virus pneumonia after hematopoietic cell transplantation (HCT): associations between viral load in bronchoalveolar lavage samples, viral RNA detection in serum samples, and clinical outcomes of HCT. J Infect Dis. 2010; 201(9): 1404-1413. [PubMed: 20350162]

249. Don M, Korppi M. Serologically defined human metapneumovirus in pediatric communityacquired pneumonia. J Pediatr. 2011; 158(1):173. [PubMed: 21030038]

250. Wyde PR, Chetty SN, Jewell AM, Boivin G, Piedra PA. Comparison of the inhibition of human metapneumovirus and respiratory syncytial virus by ribavirin and immune serum globulin in vitro. Antiviral Res. 2003; 60(1):51-59. [PubMed: 14516921]

251. Safdar A. Immune modulatory activity of ribavirin for serious human metapneumovirus disease: early i.v. therapy may improve outcomes in immunosuppressed SCT recipients. Bone Marrow Transplant. 2008; 41(8):707-708. [PubMed: 18347567] 
252. Abdul-Rasool S, Fielding BC. Understanding human coronavirus HCoV-NL63. Open Virol J. 2010; 4:76-84. [PubMed: 20700397]

253. Tyrrell DA, Bynoe ML. Cultivation of a novel type of common-cold virus in organ cultures. BMJ. 1965; 1(5448):1467-1470. [PubMed: 14288084]

254. Hamre D, Procknow JJ. A new virus isolated from the human respiratory tract. Proc Soc Exp Biol Med. 1966; 121(1):190-193. [PubMed: 4285768]

255. Woo PCY, Lau SKP, Chu CM, et al. Characterization and complete genome sequence of a novel coronavirus, coronavirus HKU1, from patients with pneumonia. J Virol. 2005; 79(2):884-895. [PubMed: 15613317]

256. van der Hoek L, Pyrc K, Jebbink MF, van der H, et al. Identification of a new human coronavirus. Nat Med. 2004; 10(4):368-373. [PubMed: 15034574]

257. Pyrc K, Jebbink MF, Berkhout B, van der Hoek L. Genome structure and transcriptional regulation of human coronavirus NL63. Virol J. 2004; 1:7. [PubMed: 15548333]

258. Milano F, Campbell AP, Guthrie KA, et al. Human rhinovirus and coronavirus detection among allogeneic hematopoietic stem cell transplantation recipients. Blood. 2010; 115(10):2088-2094. [PubMed: 20042728]

259. Garbino J, Crespo S, Aubert JD, et al. A prospective hospital-based study of the clinical impact of non-severe acute respiratory syndrome (Non-SARS)-related human coronavirus infection. Clin Infect Dis. 2006; 43(8):1009-1015. [PubMed: 16983613]

260. Folz RJ, Elkordy MA. Coronavirus pneumonia following autologous bone marrow transplantation for breast cancer. Chest. 1999; 115(3):901-905. [PubMed: 10084516]

261. Oosterhof L, Christensen CB, Sengeløv H. Fatal lower respiratory tract disease with human corona virus NL63 in an adult haematopoietic cell transplant recipient. Bone Marrow Transplant. 2010; 45(6):1115-1116. [PubMed: 19820731]

262. Arruda E, Pitkäranta A, Witek TJ Jr, Doyle CA, Hayden FG. Frequency and natural history of rhinovirus infections in adults during autumn. J Clin Microbiol. 1997; 35(11):2864-2868. [PubMed: 9350748]

263. Liu M, Worley S, Arrigain S, et al. Respiratory viral infections within one year after pediatric lung transplant. Transpl Infect Dis. 2009; 11(4):304-312. [PubMed: 19422670]

264. Garbino J, Gerbase MW, Wunderli W, et al. Lower respiratory viral illnesses: improved diagnosis by molecular methods and clinical impact. Am J Respir Crit Care Med. 2004; 170(11):11971203. [PubMed: 15361367]

265. Hassan IA, Chopra R, Swindell R, Mutton KJ. Respiratory viral infections after bone marrow/ peripheral stem-cell transplantation: the Christie hospital experience. Bone Marrow Transplant. 2003; 32(1):73-77. [PubMed: 12815481]

266. Gutman JA, Peck AJ, Kuypers J, Boeckh M. Rhinovirus as a cause of fatal lower respiratory tract infection in adult stem cell transplantation patients: a report of two cases. Bone Marrow Transplant. 2007; 40(8):809-811. [PubMed: 17704788]

267. Liu M, Mallory GB, Schecter MG, et al. Long-term impact of respiratory viral infection after pediatric lung transplantation. Pediatr Transplant. 2010; 14(3):431-436. [PubMed: 20214745]

268. Crooks BN, Taylor CE, Turner AJ, et al. Respiratory viral infections in primary immune deficiencies: significance and relevance to clinical outcome in a single BMT unit. Bone Marrow Transplant. 2000; 26(10):1097-1102. [PubMed: 11108309]

269. Costa C, Bergallo M, Cavallo R. Detection of human bocavirus in bronchoalveolar lavage from Italian adult patients. J Clin Virol. 2009; 45(1):81-82. [PubMed: 19324589]

270. Parody R, Rabella N, Martino R, et al. Upper and lower respiratory tract infections by human enterovirus and rhinovirus in adult patients with hematological malignancies. Am J Hematol. 2007; 82(9):807-811. [PubMed: 17563077]

271. Kaiser L, Aubert J-D, Pache J-C, et al. Chronic rhinoviral infection in lung transplant recipients. Am J Respir Crit Care Med. 2006; 174(12):1392-1399. [PubMed: 17008640]

272. Gerna G, Piralla A, Rovida F, et al. Correlation of rhinovirus load in the respiratory tract and clinical symptoms in hospitalized immunocompetent and immunocompromised patients. J Med Virol. 2009; 81(8):1498-1507. [PubMed: 19551831] 
273. Costa C, Bergallo M, Sidoti F, et al. What role for human rhinoviruses in the lower respiratory tract? New Microbiol. 2009; 32(1):115-117. [PubMed: 19382677]

274. Jefferson TO, Tyrrell D. Antivirals for the common cold. Cochrane Database Syst Rev. 2001; (3):CD002743. [PubMed: 11687023]

275. Allander T, Tammi MT, Eriksson M, Bjerkner A, Tiveljung-Lindell A, Andersson B. Cloning of a human parvovirus by molecular screening of respiratory tract samples. Proc Natl Acad Sci U S A. 2005; 102(36):12891-12896. [PubMed: 16118271]

276. Maggi F, Andreoli E, Pifferi M, Meschi S, Rocchi J, Bendinelli M. Human bocavirus in Italian patients with respiratory diseases. J Clin Virol. 2007; 38(4):321-325. [PubMed: 17336143]

277. Heegaard ED, Brown KE. Human parvovirus B19. Clin Microbiol Rev. 2002; 15(3):485-505. [PubMed: 12097253]

278. Vicente D, Cilla G, Montes M, Pérez-Yarza EG, Pérez-Trallero E. Human bocavirus, a respiratory and enteric virus. Emerg Infect Dis. 2007; 13(4):636-637. [PubMed: 17553287]

279. Schenk T, Strahm B, Kontny U, Hufnagel M, Neumann-Haefelin D, Falcone V. Disseminated bocavirus infection after stem cell transplant. Emerg Infect Dis. 2007; 13(9):1425-1427. [PubMed: 18252130]

280. Lau SKP, Yip CCY, Que T-L, et al. Clinical and molecular epidemiology of human bocavirus in respiratory and fecal samples from children in Hong Kong. J Infect Dis. 2007; 196(7):986-993. [PubMed: 17763318]

281. Miyakis S, van Hal SJ, Barratt J, Stark D, Marriott D, Harkness J. Absence of human bocavirus in bronchoalveolar lavage fluid of lung transplant patients. J Clin Virol. 2009; 44(2):179-180. [PubMed: 19083266]

282. Christensen A, Nordbø SA, Krokstad S, Rognlien AG, Døllner H. Human bocavirus in children: mono-detection, high viral load and viraemia are associated with respiratory tract infection. J Clin Virol. 2010; 49(3):158-162. [PubMed: 20833582]

283. Williams JV. Déjá vu all over again: Koch's postulates and virology in the 21 st century. J Infect Dis. 2010; 201(11):1611-1614. [PubMed: 20415534]

284. Manteufel J, Truyen U. Animal bocaviruses: a brief review. Intervirology. 2008; 51(5):328-334. [PubMed: 19023216]

285. Don M, Söderlund-Venermo M, Hedman K, Ruuskanen O, Allander T, Korppi M. Don't forget serum in the diagnosis of human bocavirus infection. J Infect Dis. 2011; 203(7):1031-1032. author reply 1032-1033. [PubMed: 21402553]

286. Burton CM, Carlsen J, Mortensen J, Andersen CB, Milman N, Iversen M. Long-term survival after lung transplantation depends on development and severity of bronchiolitis obliterans syndrome. J Heart Lung Transplant. 2007; 26(7):681-686. [PubMed: 17613397]

287. Welsh RM, Markees TG, Woda BA, et al. Virus-induced abrogation of transplantation tolerance induced by donor-specific transfusion and anti-CD154 antibody. J Virol. 2000; 74(5):2210-2218. [PubMed: 10666251]

288. Winter JB, Gouw AS, Groen M, Wildevuur C, Prop J. Respiratory viral infections aggravate airway damage caused by chronic rejection in rat lung allografts. Transplantation. 1994; 57(3): 418-422. [PubMed: 8108878]

289. Kuo E, Bharat A, Goers T, et al. Respiratory viral infection in obliterative airway disease after orthotopic tracheal transplantation. Ann Thorac Surg. 2006; 82(3):1043-1050. [PubMed: 16928532] 